\author{
UNIVERSIDADE DE SÃO PAULO \\ INSTITUTO DE QUÍMICA DE SÃO CARLOS \\ PROGRAMA DE PÓS-GRADUAÇÃO/ DOUTORADO/ IQSC/USP
}

\title{
ESTUDOS DE FENÔMENOS DE OSTEOGÊNESE EM IMPLANTES \\ DE POLÍMERO VEGETAL
}

Aluno: Wallace Rocha Saran

Orientador: Prof. Dr. Gilberto Orivaldo Chierice

São Carlos 
Este exemplar foi revisado e alterado em relação à versão original, sob a exclusiva responsabilidade do autor.

São Carlos, 


\section{A Deus,}

Deus é verdade. E a verdade é a vida. É o amor definido pela união do nosso ser com os próximos. Humilde operário de Deus, na pesquisa científica há a possibilidade de rezar com submissão, dedicação e adoração a Deus em comunhão com o próximo.

\section{AOS MEUS PAIS,}

À memória de Orides Gentil Saran, meu pai, referência eterna que cativava pelo carinho e dedicação com que a todos atendia. Figura humana que jamais deixou de cumprir com competência e idealismo a tarefa de professor público, transmitiu o exemplo, o caminho, a materialização do amor, a presença do mistério decifrado da vida a seus três filhos, formados em Universidades. E à minha querida mãe, Amélia Rocha Saran, também educadora da escola pública, a minha eterna gratidão.

\section{À MINHA ESPOSA E FILHOS,}

A família, uma dimensão da criação da vida pelo amor, é uma dádiva de Deus. Com a Alena minha esposa, encontrei a felicidade de criar uma família. Junto com meus filhos, Ana Carolina, Giovanna e Wallace, hoje filhos queridos, que se despedem da infância para viver o início da adolescência e juventude, na plenitude das descobertas num lar cristão. 


\section{AO PROFESSOR DOUTOR GILBERTO ORIVALDO CHIERICE,}

Diante dos modismos que inundam a atual fase da história, recebi do Professor Gilberto Orivaldo Chierice, uma lição do viver:- a pesquisa sendo busca do novo, especificamente do "não" e do "menos conhecido"; além de ser um desafio, traz uma perene procura de benefícios de fundo social, um melhoramento da vida planetária, como finalidades do conhecimento. Seu perfil de educador é um incentivo. Obrigado pela orientação e ensinamentos e por ter proporcionado o desenvolvimento deste trabalho de pesquisa.

\section{À PROFESSORA DOUTORA LEA ASSED BEZERRA DA SILVA,}

A Professora Lea Assed Bezerra da Silva tem a capacidade de unir o sonho com a realidade, o plano com a plena execução, de descobrir talentos com vocação à pesquisa científica, aqui e no exterior. Autora de obras especializadas tem sempre prioritariamente a visão social do ensino universitário. Seu apoio irrestrito ao desenvolvimento do meu trabalho foi para mim valioso incentivo. Muito obrigada, Professora Lea.

\section{À PROFESSORA DOUTORA SADA ASSED,}

A Professora Sada Assed, com seu perfil de educadora que incentiva, criou condições para que esta pesquisa se ultimasse, ao disponibilizar setores da Faculdade de Odontologia de Ribeirão Preto, para a fase experimental. Muito obrigado pelo apoio e auxílio dispensados. 


\section{AO PROFESSOR SALVADOR CLARO NETO,}

Docente do Departamento de Química de São Carlos, da Universidade de São Paulo, um agradecimento especial, por seus valiosos ensinamentos e apoio, ao fornecer o material necessário para viabilizar o desenvolvimento da pesquisa.

\section{AO PROFESSOR DOUTOR FRANCISCO WANDERLEY GARCIA DE PAULA E SILVA,}

Meu especial agradecimento. Seu apoio foi fundamental na pesquisa, não escondendo sua capacidade pedagógica e profissional a serviço da Universidade, seja apresentando soluções ou na escolha de materiais, sempre com uma postura de culto à amizade na convivência diária, disponibilizando tempo e dedicação, para a concretização deste trabalho.

\section{AO PROFESSOR DR. PAULO NELSON FILHO,}

Professor Titular da Faculdade de Odontologia de Ribeirão Preto, da Universidade de São Paulo, sua colaboração mostrou-se indispensável, pela experiência em pesquisas, ensinamentos na área abordada e auxílio voluntário, suas lições conduziram à finalização da pesquisa. Muito obrigado.

\section{À PROFESSOR DOUTORA RAQUEL ASSED BEZERRA DA SILVA,}

Pela importante colaboração na pesquisa bibliográfica do tema abordado e conhecimentos transmitidos, num irrestrito e voluntário auxílio, para a realização deste trabalho. 


\section{À PROFESSORA DOUTORA LIZETI TOLEDO DE OLIVEIRA RAMALHO,}

Meu especial agradecimento e admiração. Suas lições sobre a importância de leituras de resultados para uma pesquisa e o rigor de suas aferições foram significantes para o desenvolvimento deste trabalho.

\section{AO PROFESSOR DR. MARCELO H. P. NOGUEIRA,}

Como médico radiologista, muito obrigado por seu auxílio, atenção e entusiasmo, na execução e avaliação das tomografias, apoio indispensável para a realização da pesquisa.

\section{AO PROFESSOR DR. JOSÉ ÁLVARO GONÇALVES JÚNIOR,}

Meu agradecimento, por disponibilizar o Instituto de Radiologia de Ribeirão Preto, na execução do trabalho, numa demonstração de amizade e apoio.

\section{À MARIA SILVIA DE GUZZI PLEPIS,}

No Serviço de Pós-Graduação do Instituto de Química de São Carlos, da Universidade de São Paulo, pela convivência amiga, atenção e entusiasmo no desenvolvimento deste trabalho. Muito Obrigado. 


\section{AO QUÍMICO ANTONIO JOSÉ REIMER,}

No Grupo de Química Analítica e Tecnologia de Polímeros, do Instituto de Química de São Carlos, da Universidade de São Paulo, pelo incentivo e apoio na execução da pesquisa.

\section{AOS FUNCIONÁRIOS DO INSTITUTO DE QUÍMICA DE SÃO CARLOS, DA UNIVERSIDADE DE SÃO PAULO,}

Pela irrestrita colaboração e agradável convivência, durante a realização da pesquisa.

\section{AO FUNCIONÁRIO MARCO ANTONIO DOS SANTOS,}

No laboratório do Departamento de Clínica Infantil, da Faculdade de Odontologia de Ribeirão Preto, da Universidade de São Paulo, pelo significativo, importante e indispensável auxílio no processamento laboratorial histológico deste trabalho e pela atenção e apoio dispensado, um especial agradecimento.

\section{AO JÚLIO CÉSAR DE MATOS E CLÁUDIA REGINA CORRÊA DE MATOS,}

Pela indispensável colaboração dispensada, na finalização deste trabalho, mediante uma precisa impressão e diagramação. 


\section{RESUMO}

O objetivo deste estudo foi analisar a modulação da expressão de metaloproteinases da matriz-2 e -9, no tecido ósseo neoformado na interface do implante derivado do polímero da mamona (Ricinus communis) com o canal medular da tíbia de coelhos, por meio de análise histológica por microscopia óptica, tomografia computadorizada e imunoistoquímica. Foram selecionados 44 coelhos machos, Oryctolagus cuniculus, da linhagem Nova Zelândia, albinos, divididos em dois grupos, sendo o Grupo 1, composto por 12 animais controle, cujas fresagens do canal medular foram produzidas bilateralmente nas tíbias e não preenchidas e, o Grupo 2, com 30 animais, cujos canais medulares da tíbia, após fresagem, foram preenchidos bilateralmente com os cilindros derivados da poliuretana da mamona. Os animais do Grupo 1 e Grupo 2 foram divididos aleatoriamente em subgrupos experimentais, conforme as datas de eutanásia pré-determinadas em 90, 120, 150 dias após o ato operatório. Um animal não foi submetido ao procedimento de fresagem, sendo utilizado para controle histológico e outro submeteu-se à eutanásia após o implante do polímero, sendo utilizado para controle de imagem do estudo com tomografia computadorizada. Decorridos os períodos experimentais, os animais foram submetidos à eutanásia, as peças removidas e encaminhadas para o exame tomográfico; posteriormente ao processamento histológico, as lâminas foram analisadas em microscópio óptico. As Metaloproteinases da Matriz (MMPs) são um importante grupo de enzimas proteolíticas zinco-dependentes responsáveis pela degradação de matriz extracelular e membranas basais. As enzimas são secretadas em uma forma latente e se tornam ativadas no ambiente pericelular, sendo relacionadas a processos fisiológicos e patológicos. No presente estudo, foram revisados alguns aspectos importantes das MMPs, discutindo-se o papel dessas enzimas em processos fisiológicos como a neoformação e maturação óssea (MMP-2). Dentre os processos patológicos que envolvem a participação das MMPs, destacam-se a reabsorção óssea e processos inflamatórios (MMP-9). A expressão de metaloproteinase da matriz-2 e -9 nos tecidos foi avaliada por meio de imunoistoquímica. Os dados obtidos foram submetidos à análise estatística por meio do teste ANOVA seguido pelo pós-teste de Tukey $(\alpha=0,05)$. No grupo experimental, aos 90 dias, a interface com o polímero apresentava uma camada espessa de tecido ósseo neoformado rico em osteócitos, o qual apresentou uma maturação com o passar do tempo, aos 120 e 150 dias pós-implantação. No grupo controle, a superfície interna junto ao canal medular apresentava-se revestida por osteoblastos, seguida de faixa de tecido ósseo, com poucas lacunas preenchidas por osteócitos. O amadurecimento do tecido da superfície interna medular acontece na região interior, sendo o osso alamelar, constituído por fibras colágenas menos amadurecidas que o osso lamelar. As imagens tomográficas 
demonstraram não haver espaço entre a superfície do material e do osso na interface implante/ medula óssea, sendo a densidade dos tecidos nesta interface semelhante à densidade das demais porções da medula óssea. O processo de remodelação óssea observado histologicamente foi acompanhado pela modulação positiva de metaloproteinase da matriz-2 durante todo o período de avaliação com baixa expressão de metaloproteinase da matriz-9.

Palavras-chave: poliuretana da mamona, implantes intramedulares, tomografia computadorizada, metaloproteinase da matriz-2, metaloproteinase da matriz-9, remodelação óssea. 


\section{ABSTRACT}

The aim of this study was to evaluate the modulation of matrix metalloproteinase- 2 (MMP-2) and -9 (MMP-9) expression in newly formed bone tissue at the interface between implant derived from castor oil (Ricinus communis) polymer and the medullary canal of rabbit tibia, by histological examination under optical microscopy, computed tomography (CT) and immunohistochemical analysis. For such purpose, 44 rabbits (Oryctolagus cuniculus, New Zealand, albinus) were selected and assigned to two groups. In Group 1, composed of 12 animals (control), reamings of the medullary canal were produced bilaterally in the tibiae of the rabbits and were not filled. In Group 2, composed of 30 animals, the tibial medullary canals, after reaming, were filled bilaterally with cylinders derived from castor oil polyurethane. The animals of Groups 1 and 2 were randomly divided in experimental subgroups, according to the periods of predetermined euthanasia, which were 90, 120, 150 days postoperatively. One animal was not subjected to the reaming procedure, and served as a histological control; another animal was killed after placement of the polymer implant, and served as a control for CT imaging. Euthanasia was undertaken at the established experimental periods, and the anatomic specimens were removed and subjected to CT analysis. Then, after histological processing, the slides were examined under optical microscopy. MMPs are an important group of zinc-dependent proteolytic enzymes responsible for the degradation of extracellular matrix and basal membranes. The enzymes are synthesized in a latent form and are activated in the pericellular environment, being involved in physiological and pathological processes. In the present study, some important aspects of MMPs were reviewed, and the role of these enzymes in physiological processes, such as new bone formation and bone maturation (MMP-2), was discussed. Among the pathological processes that have the participation of MMPs, the most relevant are bone resorption and inflammatory processes (MMP-9). MMP-2 and MMP-9 expression in the tissues was evaluated by immunohistochemistry. Data were subjected to statistical analysis by ANOVA and Tukey post-test $(\alpha=0.05)$. In the group experimental, at 90 days, the interface with the polymer presented a thick layer of newly formed bone tissue rich in osteocytes. This tissue exhibited an ongoing maturation at 120 and 150 days post-implantation. In the control group, the internal surface close to the medullary canal was lined by osteoblasts, followed by a bone tissue zone with few lacunae filled with 
osteocytes. Maturation of the tissue of the medullary internal surface occurred in the inner region, with the bone being alamellar, that is, constituted of collagen fibers less maturated than the lamellar bone. The CT scans showed no space between the material surface and the bone at the implant/bone marrow interface, and the density of the tissues at this interface was similar to the density measured in the other regions of the bone marrow. The bone remodeling process observed histologically was accompanied by positive modulation of MMP-2 during the entire evaluation period and low MMP-9 expression.

Key Words: castor oil (Ricinus communis) polyurethane, intra-medullary implants, computed tomography, matrix metalloproteinase-2, matrix metalloproteinase-9, bone remodeling. 


\section{SUMÁRIO}

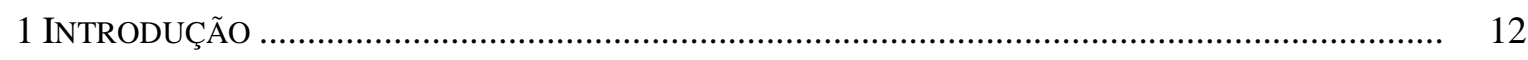

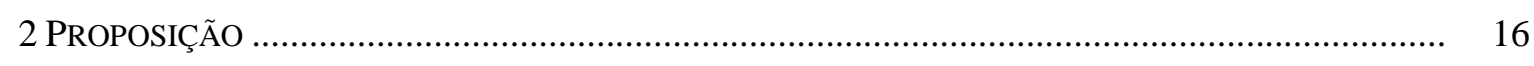

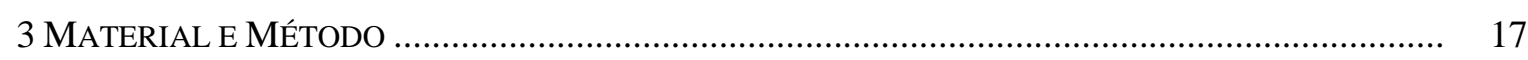

PROCESSAMENTO E ANALÍSE HISTOLÓGICA.............................................................. 22

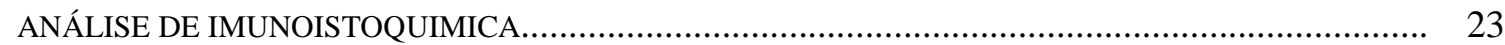

EXAME RADIOGRÁFICO E TOMOGRÁFICO............................................................................... 24

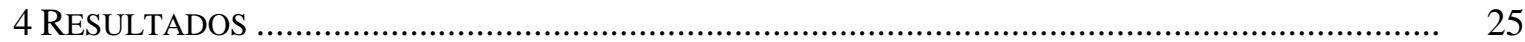

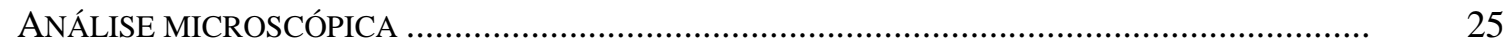

ANÁLISE IMUNOISTOQUÍMICA.................................................................................... 39

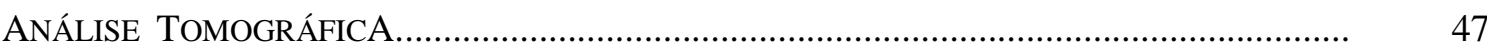

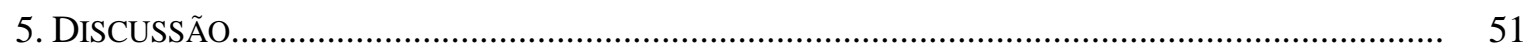

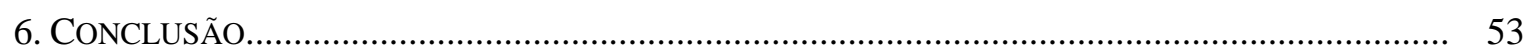

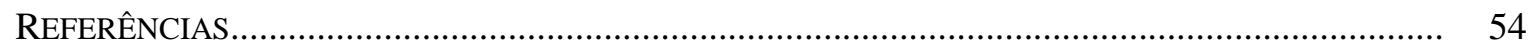




\section{INTRODUÇÃO}

O tecido ósseo é uma forma especializada de tecido conjuntivo, de consistência rígida que desempenha funções como suporte dos tecidos moles, proteção de órgãos vitais e apoio à musculatura esquelética, possibilitando a formação de um sistema de alavancas que amplia as forças geradas pela contração muscular. Além disso, os ossos funcionam como depósito de íons como cálcio e fosfato, armazenando-os ou liberando-os de forma controlada, de acordo com suas concentrações nos líquidos corporais (Junqueira e Carneiro, 2005).

Em função disso, áreas como a Ortopedia e a Traumatologia vêm se preocupando, há décadas, com materiais e técnicas que favoreçam a fixação e o reparo de fraturas ósseas ocasionadas por traumatismos, infecções, tumores e malformações congênitas, bem como com a fixação das áreas fraturadas (Kumar et al., 2005).

Estes procedimentos deveriam ser efetuados, preferencialmente, com enxertos livres de osso autógeno (Korlof et al., 1973) ou tecidos homólogos, heterólogos, descalcificados ou, ainda, por meio de transferência óssea empregando a microcirurgia (Frascino, 1998). Todos esses métodos vêm sendo utilizados e aperfeiçoados, apresentando resultados satisfatórios (Santoni-Rugiu, 1969; Tessier, 1982). No entanto, a complexidade da reparação de diferentes deformidades, tendo como fatores determinantes sua localização e dimensões (Van De Putte, 1965; Yamada, 1992), conduziu os pesquisadores à busca de materiais aloplásticos ou biomateriais. Assim, com o desenvolvimento da indústria química, resinas sintéticas vêm sendo desenvolvidas e empregadas como biomateriais, como os polietilenos, as cerâmicas (hidroxipatita, aluminato de cálcio e fosfato tricálcico) (Jarcho, 1981; Miller et al., 1991), o silicone, o titânio e o polimetilmetacrilato.

Com relação à fixação de fraturas, atualmente busca-se um biomaterial que apresente resistência, a fim de proporcionar uma fixação rígida e que, ao mesmo tempo, possa ser osteocondutor, com propriedades osteogênicas. Dentre os materiais inertes, o polímero à base de moléculas de mamoma, desenvolvido em 1984 por pesquisadores do grupo de Química Analítica e Tecnologia de Polímeros de São Carlos - Universidade de São Paulo (Chierice, 1994) tem evidenciado propriedades promissoras, incluindo osteocondução e osteogênese (Ignácio et al., 1997).

O desenvolvimento dos poliuretanos utilizados em enxertos derivados de óleo de mamona teve origem na década de 1940 (Baadsgaard, 1970; Boer, 1988; Bonini, 1999), quando foram sintetizados polímeros para aplicação como tintas e vernizes.

A mamona é um vegetal tropical típico do Brasil (Ricinus communis), da classe Dicotiledônea, ordem geraneaces e família Euforbaceaes. 
A poliuretana deriva-se de um poliéster sintetizado a partir do óleo de mamona e difenilmetanodiisocianato, composto por carbonato de cálcio, poliol derivado do polímero poliuretano da mamona e pré-polímero rico em NCO livre, derivado do difenilmetanodiisocianato e poliol poliéster.

A poliuretana sintetizada a partir do óleo de mamona é um biomaterial que vem sendo amplamente estudado para aplicação na área médica evidenciando propriedades mecânicas adequadas (Claro-Neto, 1997). Além disso, é biocompatível quando em contato com culturas de células e tecido conjuntivo e quando empregada sob a forma de implantes ou enxertos (Bonini, 1999; Ara, 1999; Bonini et al., 2002a; Bonini et al., 2002b) em leitos subperiósticos (Puricelli et al., 1999) ou em tecido ósseo (Lamano-Carvalho et al., 1997; König-Júnior et al., 1999; ; Teixeira e Ramalho, 1999;; Garcia-Júnior, 2000; Cavalieri et al., 2001; Ignácio et al., 2002; Souza et al., 2002; Del Carlo et al., 2003; Leonel et al., 2003; Ribeiro, 2003; Leonel et al., 2004; Popak et al., 2004; Saran, 2006).

Os polímeros têm demonstrado serem excelentes materiais para implantes biológicos na cirurgia ortopédica, neurocirurgia e na otorrinolaringologia, devido suas propriedades, como tolerabilidade química e biocompatibilidade. Eles também foram estudados em Odontologia como substitutos de ossos nas cirurgias bucomaxilofaciais, na busca da regeneração óssea (Carvalho et al., 1997).

Dentre as propriedades exigidas para um biomaterial, é desejável que o mesmo seja biocompatível, não seja tóxico ou carcinogênico, tenha tolerabilidade química ou biológica, densidade e peso adequados, resistência mecânica e elasticidade adequada e baixo custo (Ignácio et al., 1997).

A poliuretana derivada do óleo da mamona apresenta fácil processabilidade, flexibilidade de formulação, versatilidade de temperatura de curva, controle de pico exotérmico na transição de pico líquido - gel, excelentes propriedades estruturais, ausência de emissão de vapores tóxicos, baixo custo e é biodegradável (Ignácio et al., 1997).

Os biomateriais têm sido propostos para as áreas médicas e odontológicas com o objetivo de reparar o tecido ósseo e favorecer a reabilitação do paciente. Com o crescente interesse no emprego de materiais aloplásticos, que possam ser implantados no corpo humano, a poliuretana derivada do óleo de mamona, vem ao encontro com esta finalidade, tendo como indicação, entre outras, o seu uso em técnicas de enxertia óssea. 
Entretanto, os mecanismos envolvidos no processo de remodelação tecidual frente à utilização da poliuretana da mamona devem ser investigados. Dessa maneira, paralelamente à resposta tecidual, torna-se importante avaliar os mecanismos de ação deste material. Dentre as moléculas envolvidas no processo de remodelação tecidual que ocorre no tecido ósseo em contato direto ou indireto com os biomateriais pode-se citar as metaloproteinases da matriz (MMPs), enzimas-chave para o metabolismo do colágeno, tanto em condições fisiológicas como nas alterações patológicas (Page-McCaw et al., 2007; Krane e Inada, 2008).

As MMPs fazem parte de uma importante família de endopeptidases metaldependentes que são consideradas as principais enzimas responsáveis pela remodelação dos componentes da matriz extracelular. As MMPs são secretadas na forma de proenzimas inativas, denominadas zimógenes, e são ativadas no tecido pela segmentação dos própeptídeos. Todas as MMPs contêm $\mathrm{Zn}^{++}$no sítio catalítico e requerem a presença de $\mathrm{Ca}^{++}$para sua estabilidade e atividade (Birkedal-Hansen, 1993; Krane, 1994; Krane e Inada, 2008). Estas proteinases são expressas em resposta a estímulos específicos pelas células residentes do tecido conjuntivo bem como por células recrutadas durante o processo de remodelação tecidual (Birkedal-Hansen, 1993; Krane, 1994; Pasternak e Aspenberg, 2009; Galliera et al., 2010).

As metaloproteinases da matriz são classificadas em 5 classes principais de acordo com sua especificidade por determinados substratos e de acordo com a sua morfologia estrutural interna em colagenases, gelatinases, estromelisinas, MMPs associadas à membrana e outras (Birkedal-Hansen, 1993; Krane, 1994). Existem evidências que indicam que as metaloproteinases da matriz são importantes para uma grande variedade de processos biológicos, desde o desenvolvimento e remodelação até a destruição dos tecidos (Hayakawa, 1998; Parks et al., 2004; Hannas et al., 2007; Page-McCaw et al., 2007).

A atividade das MMPs são controladas também por meio dos inibidores específicos, conhecidos como inibidores teciduais de MMPs (TIMPs). As TIMPs são proteínas pequenas e multifuncionais que regulam ambas as funções das MMPs, o nível de sua ativação e sua habilidade de hidrolisar um determinado substrato (Birkedal-Hansen, 1993; Souza e Line, 2002; Navarro et al., 2006). O equilíbrio entre a produção de MMPs e a de TIMPs representa um ponto principal para manter a homeostase da matriz extracelular. É conhecido que um processo patológico da matriz extracelular pode se instalar quando existe excesso de atividade das MMPs nos tecidos. Por essa razão, há um grande interesse em desenvolver inibidores sintéticos das MMPs que possam ser usados em terapias médicas e odontológicas (Souza e Line, 2002). 
As MMPs também participam de processos de remodelação normais, como no desenvolvimento embriológico, na involução pós-parto do útero, na remodelação óssea, na ovulação e na reparação de feridas, embora a atividade das MMPs tenha sido relacionada a importantes doenças, como destruição de articulações nos casos de artrite reumatóide, osteoartrite, aneurisma aórtico abdominal, infarto agudo do miocárdio e câncer (Navarro et al., 2006). 


\section{PROPOSIÇÃO}

O objetivo deste estudo foi analisar os fenômenos de osteogênese em implantes de polímero vegetal por meio da modulação da expressão de metaloproteinases da matriz-2 e -9 através da imunoistoquímica, da análise histológica por microscopia óptica e tomografia computadorizada. 


\section{MATERIAL E MÉTODO}

\section{Animais e procedimento experimental}

Após aprovação do projeto de pesquisa pela Comissão de Ética do Biotério da Faculdade de Odontologia de Ribeirão Preto, da Universidade de São Paulo, no Uso de Animais, processo $\mathrm{n}^{\circ}$ 06.1.343.53.3, foram selecionados 44 coelhos machos, Oryctolagus cuniculus, da linhagem Nova Zelândia, albinos, de 8 a 10 semanas, pesando aproximadamente 2,5 kg. Os animais selecionados foram divididos em grupos, sendo o Grupo 1, composto por 12 animais controle, cujas fresagens do canal medular foram produzidas bilateralmente nas tíbias não preenchidas e, o Grupo 2, com 30 animais, cujos canais medulares da tíbia, após fresagem, foram preenchidos bilateralmente com os cilindros derivados da poliuretana da mamona.

Os 30 animais foram divididos aleatoriamente em 3 subgrupos experimentais $\left(\mathrm{G}_{2 \mathrm{a}}\right.$, $\mathrm{G}_{2 \mathrm{~b}}$ e $\mathrm{G}_{2 \mathrm{c}}$ ), conforme as datas de eutanásia pré-determinadas em 90, 120, 150 dias após o ato operatório. O mesmo foi realizado no grupo controle, com mesma data de eutanásia, formando 3 grupos de 4 animais cada. Um animal não foi submetido ao procedimento de fresagem, sendo utilizado para controle histológico e outro foi submetido à eutanásia após o implante do polímero, sendo utilizado para controle de imagem do estudo com tomografia computadorizada

Tabela 1. Distribuição dos grupos experimentais, variáveis e número de animais para cada grupo experimental

\begin{tabular}{clc}
\hline Grupo & \multicolumn{1}{c}{ Variáveis } & Número de animais \\
\hline $\mathrm{G}_{1 \mathrm{a}}$ & Controle - eutanásia aos 90 dias & 4 \\
$\mathrm{G}_{1 \mathrm{~b}}$ & Controle - eutanásia aos 120 dias & 4 \\
$\mathrm{G}_{1 \mathrm{c}}$ & Controle - eutanásia aos 150 dias & 4 \\
$\mathrm{G}_{2 \mathrm{a}}$ & Experimental - eutanásia aos 90 & 10 \\
& dias & 10 \\
$\mathrm{G}_{2 \mathrm{~b}}$ & Experimental - eutanásia aos 120 & \\
& dias & 10 \\
$\mathrm{G}_{2 \mathrm{c}}$ & Experimental - eutanásia aos 150 & \\
& dias &
\end{tabular}


Inicialmente foi efetuada anestesia geral, por via endovenosa, com nembutal sódico, na dosagem de $25 \mathrm{mg} / \mathrm{kg}$ de peso e quando necessário foi realizada a suplementação anestésica, com o mesmo medicamento. A seguir, o animal foi posicionado na mesa operatória na posição de decúbito dorsal, efetuada a tricotomia dos joelhos direito e esquerdo e realizada a anti-sepsia com álcool iodado. O campo cirúrgico em ambos os joelhos possuía uma fenestração nas áreas a serem operadas. Todo o instrumental utilizado foi previamente autoclavado à $120^{\circ} \mathrm{C}$ por 20 min. e montados em campos cirúrgicos esterilizados.

Para a anestesia do coelho, foi realizada uma punção, da veia marginal da orelha, com agulhas siliconizadas, de paredes ultrafinas e bisel curto trifacetado do tipo butterfly $\mathrm{n}^{\circ}$ 21. Foi selecionado para a colocação do implante o canal medular da tíbia, por ser o mesmo mais retilíneo do que o fêmur e por apresentar via de acesso tecnicamente menos invasiva.

O polímero, derivado da mamona, em forma de cilindro, foi introduzido na face extensora do joelho no plano de dissecção medial ao tendão patelar para exposição da tíbia do coelho na sua porção extra articular, próximo à inserção deste tendão.

$\mathrm{O}$ acesso à tíbia foi realizado inicialmente por meio de uma incisão superficial de aproximadamente $1,5 \mathrm{~cm}$, utilizando uma lâmina de bisturi número 15 na face ventral e medial do joelho, próxima à inserção do tendão patelar, seguido pela exposição do tendão, e afastamento do mesmo lateralmente, com o objetivo de possibilitar a exposição da face extraarticular proximal medial da tíbia.

Para acesso ao canal medular foi iniciada a perfuração da tíbia utilizando uma broca de $2 \mathrm{~mm}$, com um motor elétrico sendo a mesma a seguir, introduzida por todo o canal medular da tíbia, com o auxílio de uma chave em " $\mathrm{T}$ " com mandril, desde a metáfise proximal até a epífese distal da tíbia do coelho.

Com o objetivo de prevenir a lesão celular por calor, provocada pela alta rotação da broca não foi utilizado o motor. Após a viabilização do canal medular da tíbia, foi introduzido um cilindro de poliuretano com carbonato de cálcio esterilizados com óxido de etileno sem ultrapassar a epífise distal da tíbia. Os cilindros de poliuretano com carbonato de cálcio foram fornecidos pelo Instituto de Química de São Carlos da Universidade de São Paulo, os quais possuíam $2 \mathrm{~mm}$ de espessura e preenchiam assim toda a extensão do canal medular. Esses cilindros foram cortados de acordo com o tamanho em extensão do canal medular, o qual possuía em média $11 \mathrm{~cm}$, ficando os mesmos justamente sepultados no canal medular ao orifício de entrada. 
A seguir, foi realizada a sutura da incisão com fio monofilamento 4-0 e a limpeza com soro fisiológico, deixando-a descoberta e sem qualquer tipo de imobilização. Os animais foram examinados semanalmente, por meio de palpação dos locais cirúrgicos, da manipulação das articulações dos joelhos, visando analisar o estado das feridas cirúrgicas, para a identificação dos sinais inflamatórios ou da deiscência da sutura, do recuo dos materiais implantados ou de outras restrições.

Decorridos os períodos experimentais, os animais foram submetidos à eutanásia, com a utilização do mesmo anestésico utilizado durante o ato operatório. Como área para estudo, foi escolhida a diáfise das tíbias nas suas porções centrais.

\section{Figura 01:}

A- Planejamento da incisão no joelho do coelho;

B- Incisão e exposição do tendão patelar;

C- Perfuração com broca, com protetor para não lesar o tendão patelar;

D- Exposição da broca.

\section{Figura 02:}

A- Introdução de toda broca no canal medular, tornando-o permeável;

B- Fio metálico utilizado para identificar o comprimento da tíbia do coelho;

C- Introdução da haste de polímero da mamona;

D- Sutura do tendão patelar. 

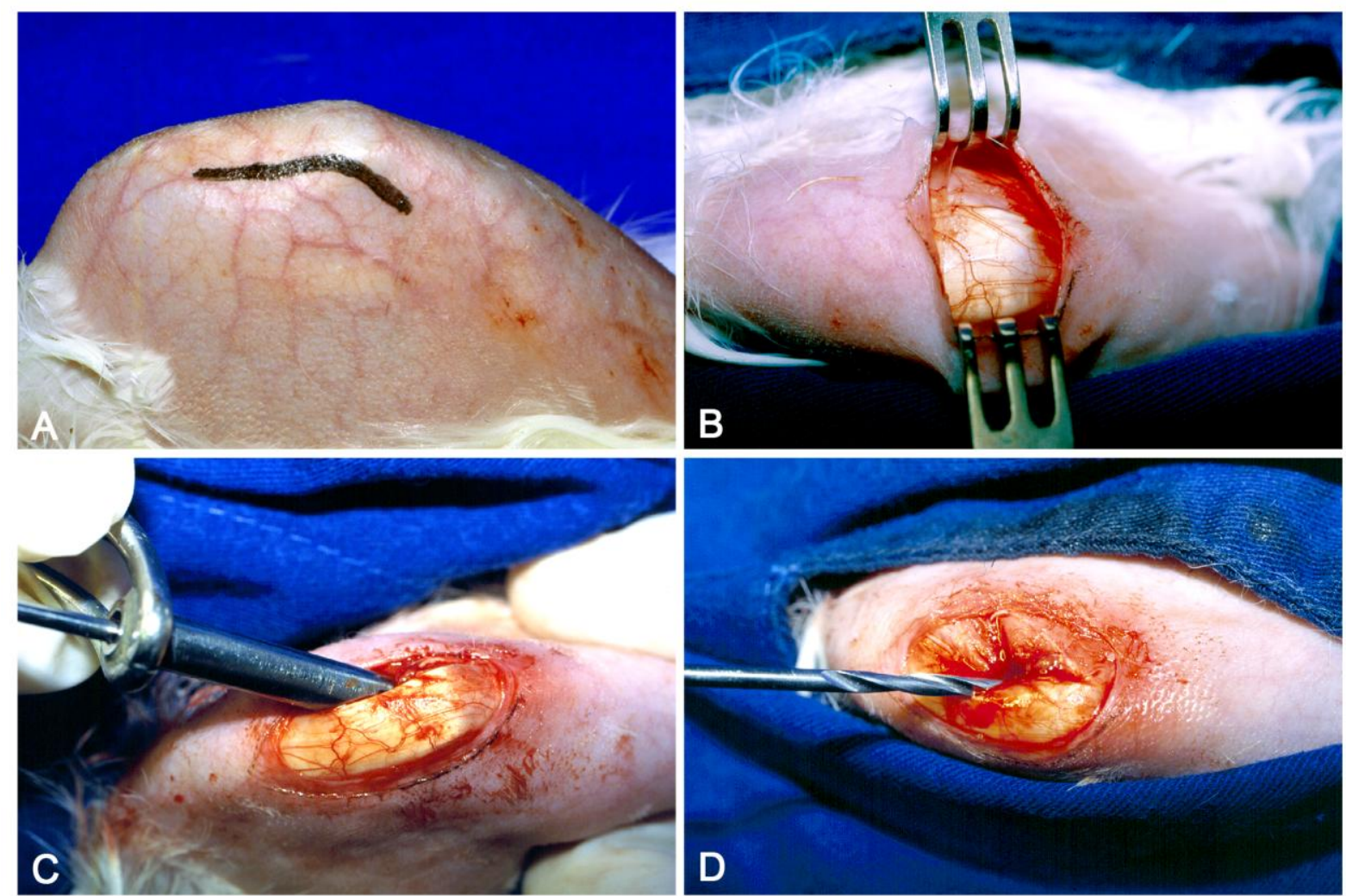

Figura 01: A- Planejamento da incisão no joelho do coelho; B- Incisão e exposição do tendão patelar; C- Perfuração com broca, com protetor para não lesar o tendão patelar; D- Exposição da broca. 

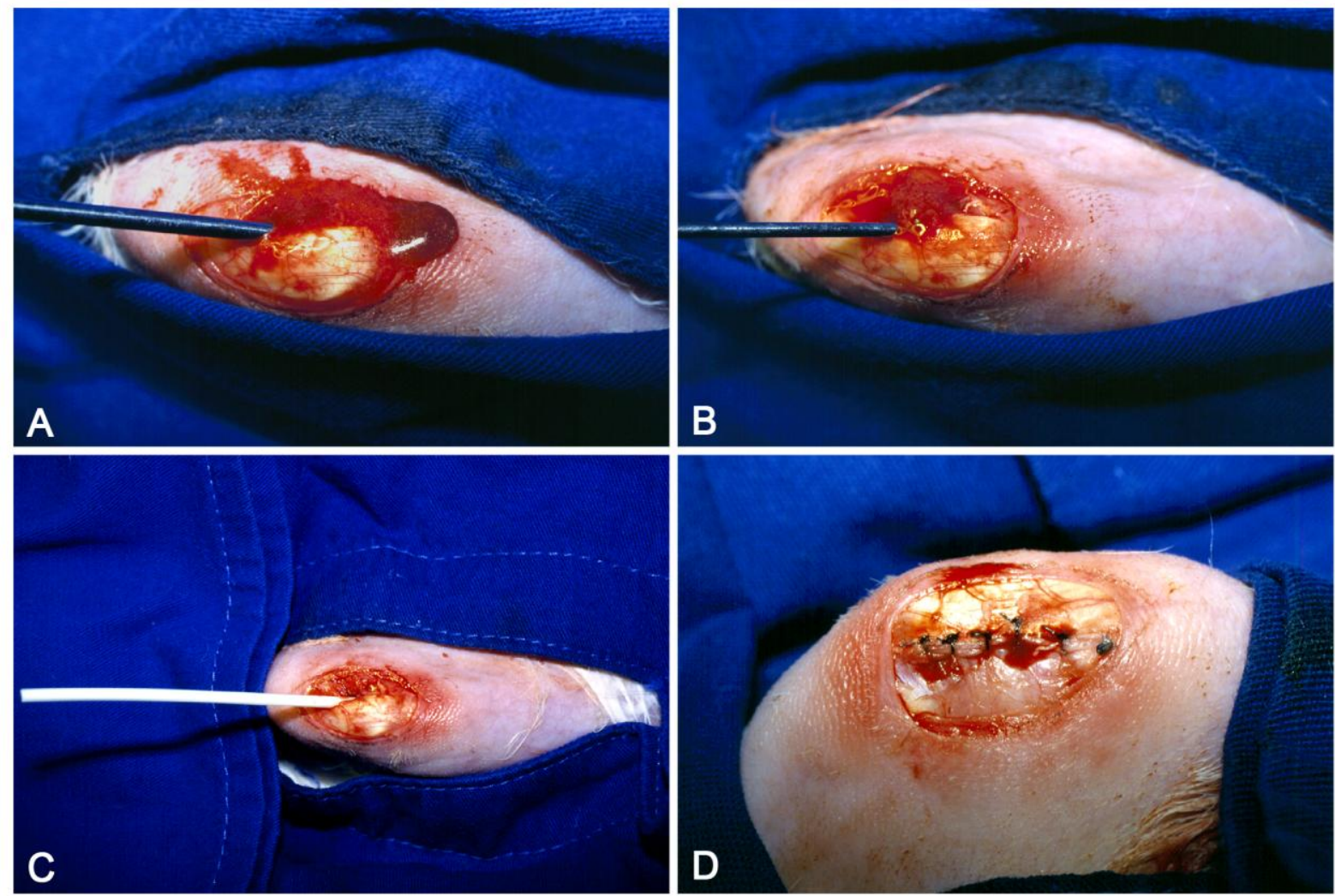

Figura 02: A- Introdução de toda broca no canal medular, tornando-o permeável; B- Fio metálico utilizado para identificar o comprimento da tíbia do coelho; C- Introdução da haste de polímero da mamona; D- Sutura do tendão patelar. 


\section{PROCESSAMENTO E ANÁLISE HISTOLÓGICA}

As peças foram submetidas à fixação em solução de formol tamponado a 10\%, por 72 horas, à temperatura ambiente. Posteriormente, foram imersas em um recipiente de vidro contendo uma solução à base de EDTA a 20\% (pH 7,4) e submetidas a desmineralização, acelerada pelo forno microondas (Sharp Carousel®, São Paulo, SP). Para a realização deste procedimento, o recipiente contendo as peças foi parcialmente imerso em outro recipiente de vidro contendo água e gelo, com o objetivo de retardar o aumento da temperatura e, consequentemente, incrementar o tempo de ação das microondas. O forno de microondas operou na frequência de trabalho de $2450 \mathrm{MHz}$, correspondendo a um $\mathrm{n}^{\circ}$ de onda no vácuo de $12,2 \mathrm{~cm}$, potência máxima nominal de $700 \mathrm{~W}$, regulado em potência média / máxima à temperatura de $30^{\circ} \mathrm{C}$ para evitar alterações teciduais. As peças foram irradiadas por 10 minutos, com intervalos de 5 minutos entre as irradiações, por um período de 4 horas por dia. A completa desmineralização das amostras, avaliada por meio da penetração de uma agulha nos tecidos para verificação da sua consistência e por meio de exame radiográfico das peças, foi obtida em aproximadamente 30 dias. Concluída a desmineralização, as peças foram neutralizadas em solução de sulfato de sódio a 5\% (Sulfato de Sódio Anhido; J.T.Baker, Xalostoc, México) por 24 horas, lavadas em água corrente por 24 horas, desidratadas em concentrações crescentes de álcool (Álcohol Etílico Absoluto Anhidro®; J.T. Baker), diafanizadas em xilol (Xylol@; Merck) e incluídas em parafina (Histosec® Pastillen; Merck). Os blocos foram reduzidos pela microtomia a cortes seriados longitudinais com 6,0 $\mu \mathrm{m}$ de espessura. Para avaliação histopatológica, as lâminas foram coradas pela Hematoxilina e Eosina (HE) para uma visão geral da morfologia celular e e pelo Tricrômico de Mallory (TM), para a análise da substância intercelular das fibras colágenas, da presença dos componentes celulares, da formação do osteóide e da mineralização.O polímero, após corte em micrótomo, foi retirado, pois o mesmo se deslocava e dificultava a analíse em microscópio. A análise histológica foi realizada subjetivamente em microscópio óptico (Zeiss Axio Imager, Carl Zeiss AG Light Microscopy, Göttingen, Alemanha), observando-se a presença ou não de um processo inflamatório e a sequência biológica envolvida no reparo do tecido ósseo.

A seqüência biológica do reparo do tecido ósseo foi baseada na verificação dos seguintes acontecimentos: 1) Calo ósseo; 2) Neoformação vascular; 3) Neoformação óssea (com a determinação dos elementos celulares envolvidos e da formação do ósteon); 4) Tecido ósseo imaturo; 5) Tecido ósseo maduro; 6) Linha reversa óssea. 


\section{ANÁLISE DE IMUNOISTOQUÍMICA}

Com o objetivo de determinar se as metaloproteinases da matriz estão envolvidas no processo de remodelação tecidual, foram realizados ensaios de imunoistoquímica para as metaloproteinases da matriz-2 e -9.

As lâminas foram desparafinizadas em xilol (3 imersões - cada imersão por 5 minutos), e hidratadas em série decrescente de alcoóis (2 imersões em álcool 100, a seguir 1 imersão em álcool 95 e 1 imersão no álcool 80 - por 2 minutos cada passagem). A seguir foram colocadas em água destilada por 5 minutos e mantidas em salina fosfatada tamponada (PBS), por mais 5 minutos. Para os ensaios de imunoistoquímica foi utilizado o sistema Goat ImmunoCruzTM (Santa Cruz Biotechnology Inc., La Jolla, EUA).

A peroxidase endógena foi bloqueada com bloqueador de peroxidase (peroxidase block), por 5 minutos. Após esse período de tempo o bloqueador foi escoado em papel absorvente e as lâminas foram lavadas em PBS por 5 minutos $(2 \times)$ e submetidas à recuperação dos epítopos antigênicos. As lâminas contendo o tecido ósseo foram recobertas com Proteinase K obtida de Engyodontium album (Sigma-Aldrich, St.Louis, EUA), diluída em água destilada deionizada a $0,05 \%$, e a seguir foram incubadas a $37^{\circ} \mathrm{C}$, durante 15 minutos.

Sequencialmente os cortes foram demarcados utilizando uma Caneta PAP Pen (Ted Pella Inc, Redding, EUA) e as lâminas foram lavadas em PBS por 5 minutos (2×). Os sítios de ligação não-específica foram bloqueados com soro de asno (Donkey serum block) por 30 minutos.

A seguir, os tecidos foram incubados com os anticorpos primários policlonais, produzidos em cabra, por duas horas a uma temperatura ambiente, para MMP-2 $(5,0 \mu \mathrm{g} / \mathrm{ml}$; sc 8835) e MMP-9 (5,0 $\mu \mathrm{g} / \mathrm{ml}$; sc - 6840), previamente titulados (concentrações variando entre 1,0 a $5,0 \mu \mathrm{g} / \mathrm{ml}$ ). A seguir as lâminas foram lavadas e incubadas com anticorpos secundários biotinilados (anti-cabra) por 30 minutos, lavadas em PBS (2×), e incubadas com estreptavidina conjugada à horseradish peroxidase (HRP) por 20 minutos e lavadas com PBS por 3 minutos $(2 \times)$. Como substrato enzimático foi utilizado 3,3'-diaminobenzidina (DAB), preparada utilizando cromógeno DAB concentrado 50×, o qual foi diluído em solução tampão concentrada 10x, e água destilada deionizada, aplicado sobre os cortes por 5 minutos. As lâminas foram lavadas em água destilada por 5 minutos, $2 \times$, contra-coradas com hematoxilina de Harris por 1 minuto, lavadas com água corrente, desidratadas em concentrações crescentes 
de álcool (1 imersão em álcool 80, a seguir 1 imersão em álcool 95 e 1 imersão no álcool 100 - por 2 minutos cada passagem), imersas em xilol e montadas em Entellan ${ }^{\circledR}$ (Merck, Darmstadt, German).

Para testar a especificidade da imunomarcação foram utilizados cortes nos quais foi omitido o anticorpo primário e as lâminas foram incubadas com imunoglobulinas obtidas da mesma espécie animal na qual o anticorpo primário foi produzido (Negative control).

O número de células positivamente marcadas foi estimado para cada anticorpo em três campos representativos no aumento de $63 \times$. Os dados obtidos foram analisados por meio do teste ANOVA seguido pelo pós-teste de Tukey $(\alpha=0,05)$.

\section{EXAME RADIOGRÁFICO E TOMOGRÁFICO}

Após as cirurgias, foram realizadas as radiografias das tíbias direitas e esquerdas dos coelhos, ainda sob efeito anestésico, para a verificação do posicionamento dos implantes, com o objetivo de avaliar a presença de falsos trajetos ou fraturas. $\mathrm{O}$ exame radiográfico foi realizado com aparelho Unimax (Siemens), com 48 kVp, 10 mA e 0,1 segundo de exposição com a ampola a uma distância de 1,0 metro do animal, em projeção antero-posterior, com a intenção de documentar o posicionamento intramedular da haste de poliuretana. Foi utilizado o filme R.H.S. (Sakura) $18 \times 24$ e "écran”, sendo a revelação realizada com processador RP X Omat da Kodak.

Após a eutanásia, foram realizados cortes tomográficos axiais de 1 milímetro de espessura com 1 milímetro de espaçamento entre os cortes. Para cada tíbia foram obtidos dois cortes contíguos na metáfise proximal, quatro cortes contíguos no terço médio da diáfise e dois cortes contíguos na metáfise distal.

Os exames tomográficos foram realizados em equipamento de tomografia computadorizada modelo Sytec Synergy GE medical Systems 1999, com software versão 3.5 A. A técnica padronizada para este estudo utilizou $120 \mathrm{kv}$ e $60 \mathrm{~mA}$, com FOV (field of view) de 23,4 centímetros. 


\section{RESULTADOS}

\section{ANÁLISE MICROSCÓPICA}

Grupo Experimental - período de 90 dias após fresagem do canal medular e implantação do polímero

Aos 90 dias, a parede óssea interna do canal medular e a interface com o polímero apresentou camada espessa de tecido ósseo neoformado, rico em osteócitos, constituindo um novo sistema fundamental externo e outro sistema fundamental aderido ao osso receptor, formando uma linha reversa de crescimento.

Este tecido encontrava-se em processo de amadurecimento considerando que as lamelas de fibras colágenas estavam se organizando de forma circular a fim de constituírem o sistema de Havers, em cuja luz há ocorrência de tecido mole e presença de vasos sanguíneos.

Figura 3A (TM)

A análise do material corado pela hematoxilina-eosina mostrou nitidamente a linha reversa que separa o osso novo do osso do leito receptor. Esta linha tortuosa fortemente corada delimitava o osso neoformado, ao longo da superfície interna do canal medular.

Figuras 3B (HE)

Nas porções em que o osso neoformado apresentava uma estreita faixa, esta apresentava inúmeros osteócitos, rodeados por matriz cujas fibras colágenas eram paralelas formando um osso do tipo primário.

Figura 3C (HE)

Em alguns locais esparsos da superfície óssea do canal medular, ocorreu uma concentração de células mononucleadas, que muitas vezes preenchia as reentrâncias do tecido ósseo.

Figura 3D (HE) 


\section{Experimental 90 dias}

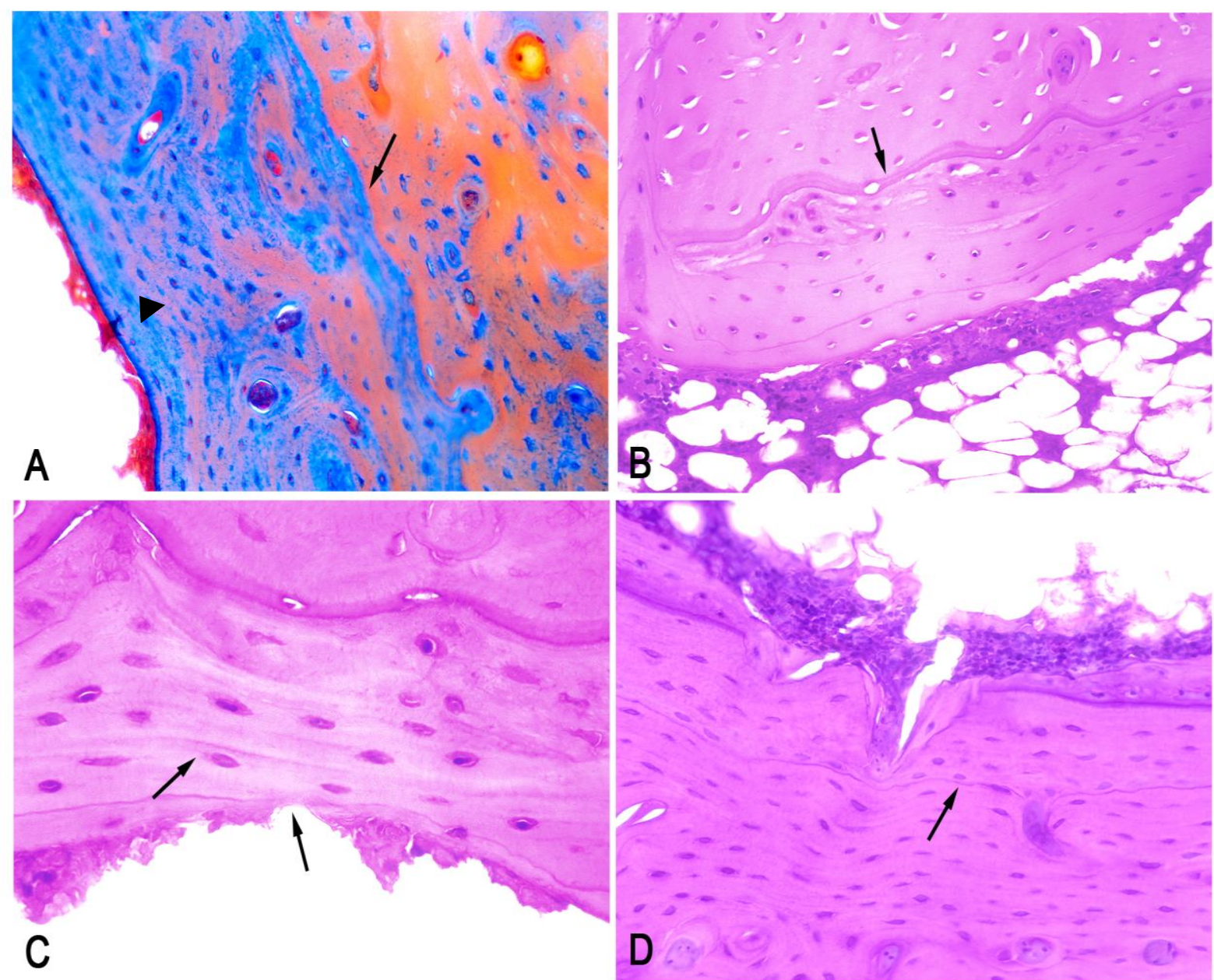

Figura 03: A- Tecido ósseo neoformado rico em osteócitos (sistema fundamental - ponta de seta) e linha reversa (seta)- TM 685X; B- Presença nítida de linha reversa (seta)HE 685X; C- Osso neoformado imaturo ou primário- HE 857X; D- Neoformação de células na superfície - HE 857X. 
Pela análise do Tricrômico de Mallory, pode-se observar os diferentes níveis de mineralização do osso neoformado por meio da coloração alaranjada e azulada das fibras colágenas.

Figuras 4A (TM)

Ocorreu com certa freqüência a presença do canal de Volkmann unindo o osso neo formado com o osso do leito receptor.

Figura 4B (TM)

Presença de osso maduro secundário em locais isolados do canal medular. Pela Hematoxilina e Eosina, o osso neoformado, aos 90 dias, tem um grau de coloração muito mais acentuado que a coloração do osso do leito receptor.

Figuras 4C (TM)

Neoformação óssea na parede interna do canal medular.

Figura 4D (TM) 


\section{Experimental 90 dias}
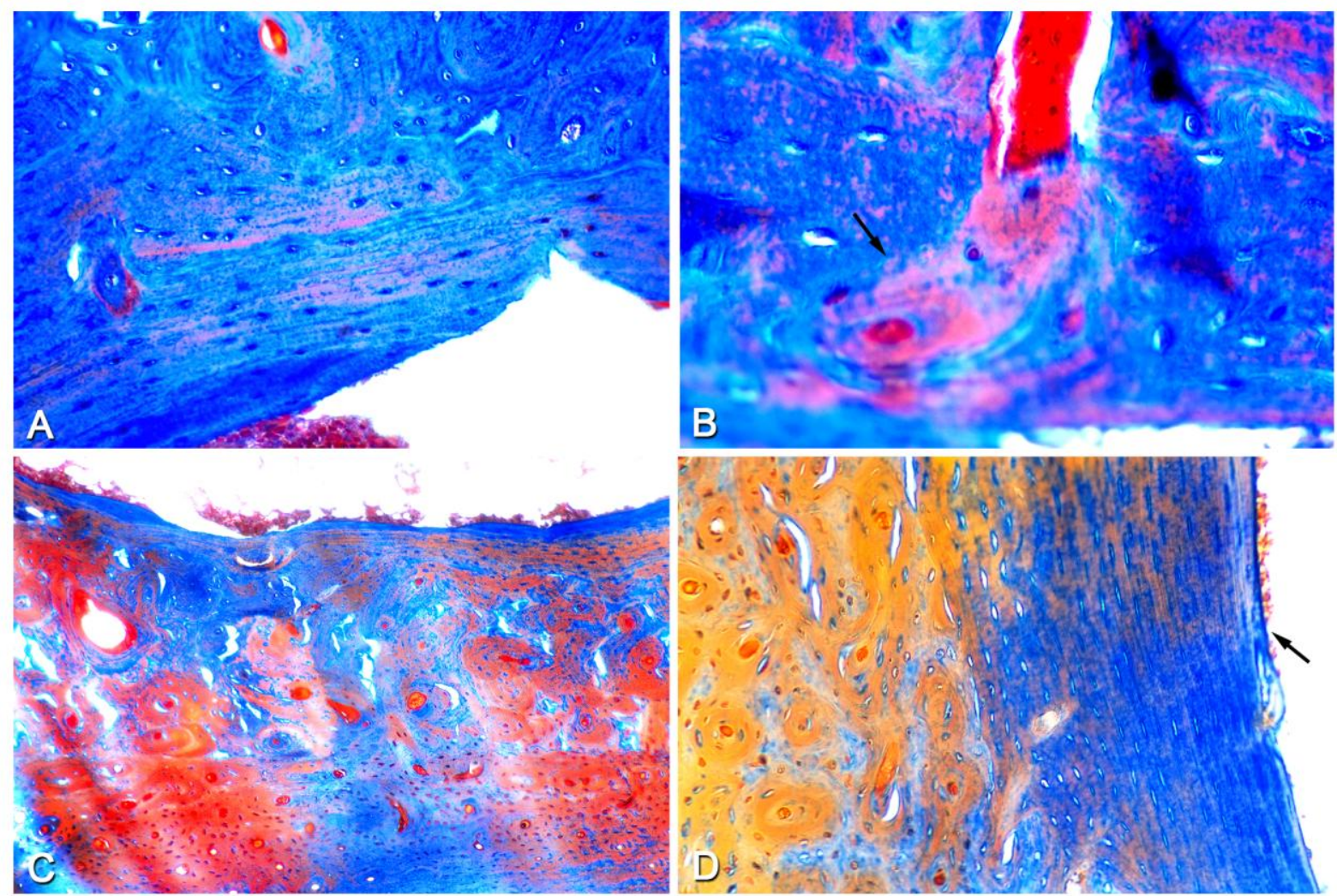

Figura 04: A- Níveis de mineralização - TM 857X; B- Canal de Volkmann - TM 857X; COsso maduro secundário - TM 265X; D- Neoformação óssea na camada interna - TM 535X. 


\section{Grupo Experimental - Período 120 dias}

Neste período de 120 dias, a superfície interna do osso neoformado encontrou-se em franco processo de amadurecimento, onde se visualizaram poucos osteócitos no interior da matriz e a organização das fibras colágenas em lamelas concêntricas, aos Canais de Havers.

Figura 5A (HE)

Observa-se a formação das lamelas concêntricas ao redor de um amplo canal de Havers, pela coloracao de Tricômico de Mallory.

Figura 5B (TM)

Ocorre a presença de lamelas concêntricas e amplos canais de Havers muito próximos do canal medular.

Figura 5C (HE)

Experimental 90 dias

A observação pelo Tricômico de Mallory mostra muito bem a ocorrência do processo de amadurecimento ósseo por meio da formação das lamelas concêntricas na superfície interna do canal medular.

Figura 5D (TM)

O osso neoformado em franco processo de amadurecimento com organização das fibras colágenas.

Figura 6A (HE)

Superfície óssea interna revestida por compacta óssea interna mostrando fibras paralelas, constituindo o chamado sistema fundamental interno. Não se nota a presença de linha reversa de crescimento.

Figura 6B (HE)

Pelo Tricômico de Mallory observam-se as lamelas concêntricas bem organizadas, com os osteócitos situados ao redor do canal de Havers como também a presença dos canais de Volkmann.

Figuras 6C (TM) 


\section{Experimental 120 dias}
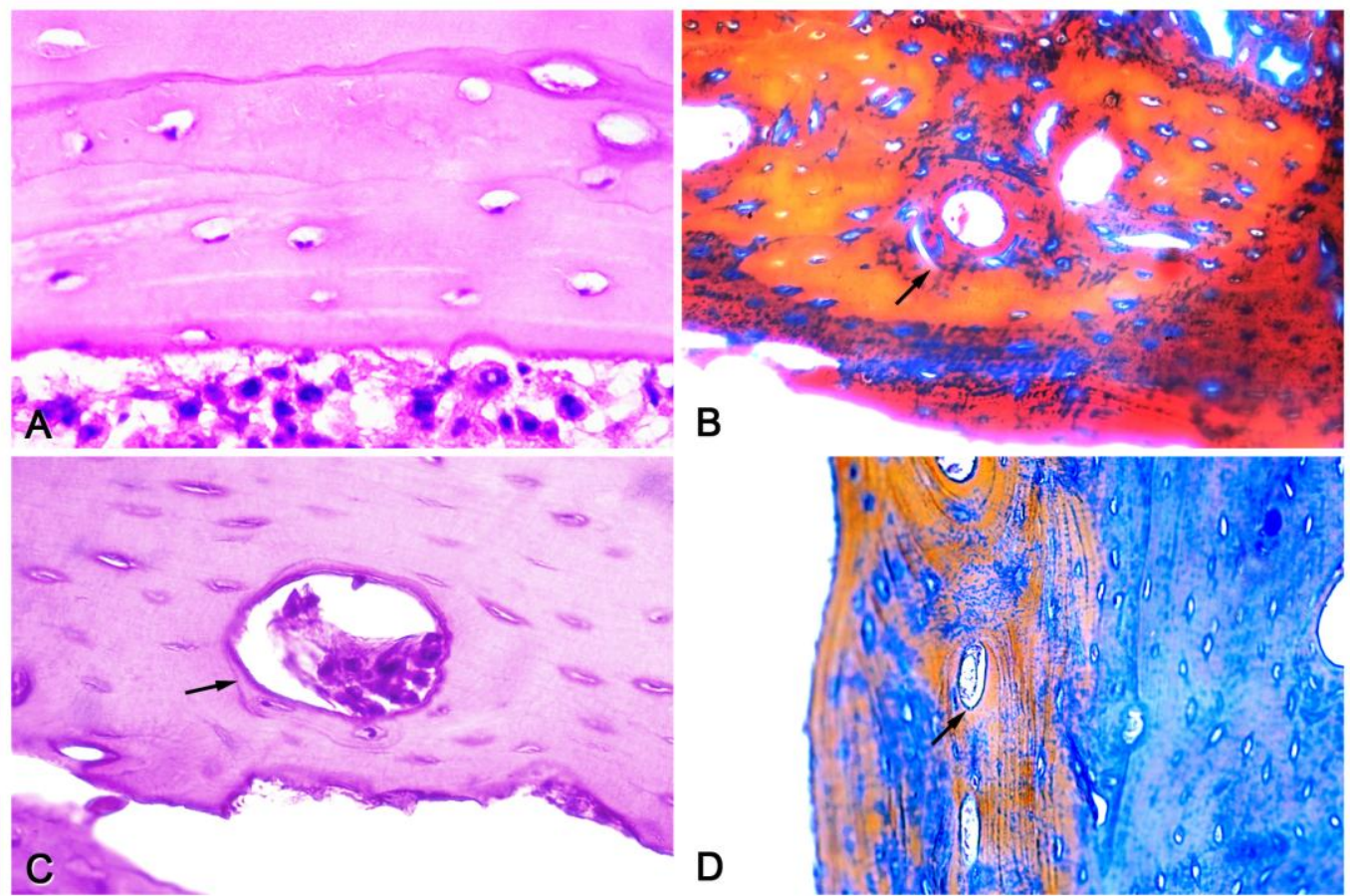

Figura 05: A- Processo de amadurecimento ósseo - HE 1071X; B- Lamelas concêntricas ao Canal de Havers - TM 857X; C- Lamela óssea junto da parede interna - HE 857X; D- Lamelas na superfície interna do canal medular - TM 857X.
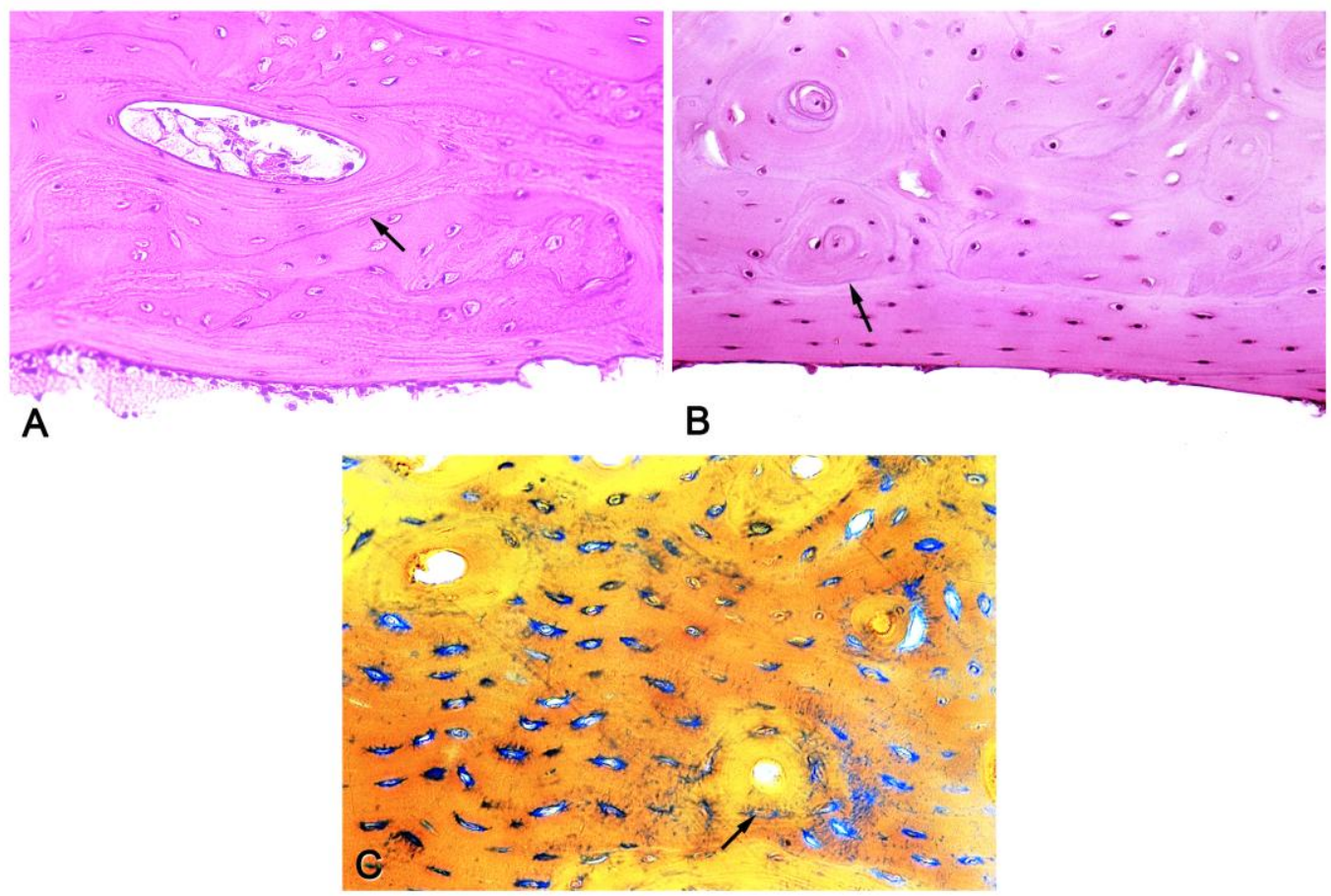

Figura 06: A-Processo de amadurecimento e organização das fibras colágenas - HE 428X; B- Tecido ósseo maduro - HE 428X; C- Osteócitos (seta) ao redor do Canal de Havers - TM 1071X. 


\section{Grupo Experimental - Período de 150 dias}

Neste período ocorreu uma diminuição de osteócitos no sistema fundamental interno, apresentando-se distantes uns dos outros, em formação paralela, demonstrando a maturidade óssea.

Figuras 7A e 7B(HE)

Restante do osso formado por lamelas concêntricas bem organizadas, característica de osso maduro.

Figura 7C (TM)

Pela Hematoxilina e Eosina, observa-se que os poucos osteócitos localizados no sistema fundamental interno preenchem a lacuna como um todo.

Figura 7D(HE) 


\section{Experimental 150 dias}

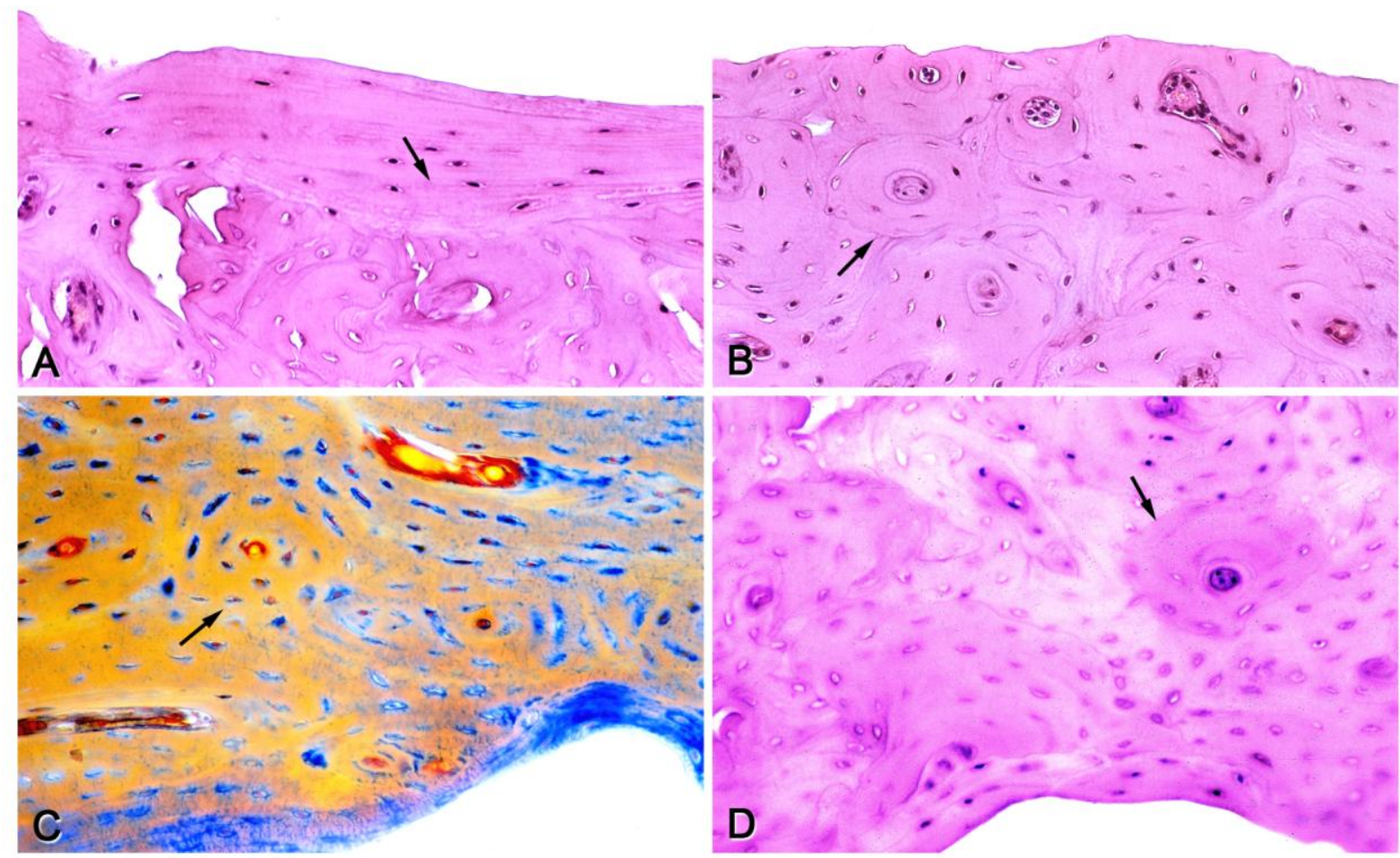

Figura 07: A- Poucos osteócitos no sistema fundamental interno - HE 535X; B- Poucos osteócitos no sistema fundamental interno - HE 535X; C- Lamelas concêntricas bem organizadas - TM 1071X; D- Osteócitos em lacunas no sistema fundamental interno - HE 1071X. 


\section{Grupo Controle - Período de 90 dias}

Aos 90 dias, observa-se o osso neoformado revestindo a parede do canal medular é rico em osteoblastos.

Figura 8A (HE)

Alinhados na superfície interna junto a medula óssea, no interior da matriz, inúmeros nichos, ocupados pelos osteócitos.

Figura 8B (HE)

Osso neoformado junto ao canal medular do tipo alamelar, ou seja, osso imaturo.

Figura 8C (HE)

O tecido neoformado junto à superfície medular com grau de amadurecimento das fibras colágenas menor que o tecido ósseo localizado à distancia.

Figura 8D (TM) 


\section{Controle - 90 dias}
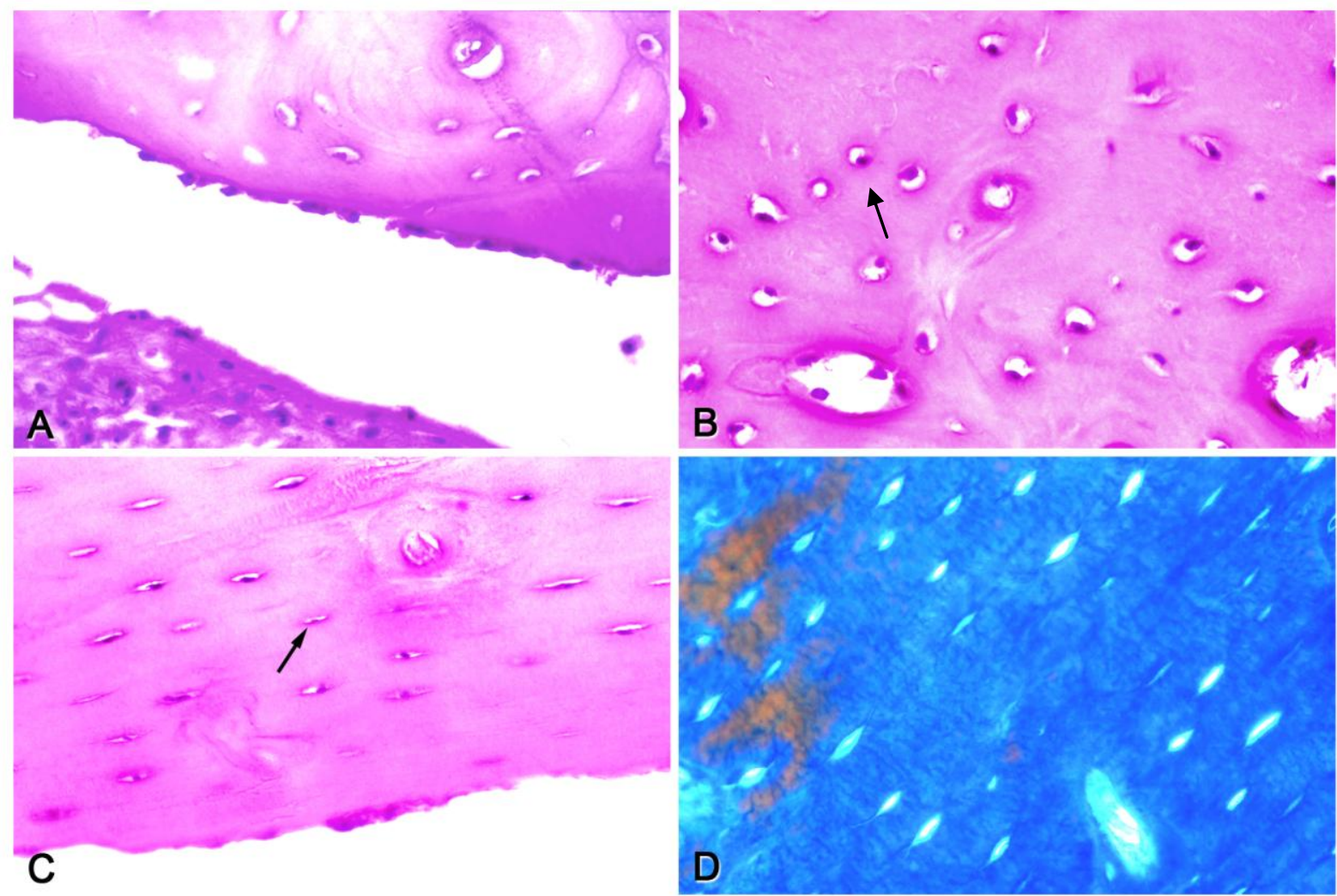

Figura 08: A- Osteoblastos revestindo o canal medular - HE 857X; B- Osteócitos na matriz óssea - HE 857X; C- Osso alamelar revestindo o canal medular - HE 857X; DDiferentes graus de amadurecimento das fibras colágenas - TM 857X. 
Grupo Controle - Período de 120 dias

A superfície interna junto ao canal medular encontrava-se revestida pelos osteoblastos, seguida de faixa de tecido ósseo, com poucas lacunas preenchidas por osteócitos e presença da linha reversa de crescimento, limitando o osso lamelar de Havers, com diâmetros homogêneos.

Os canais de Havers são preenchidos por vasos sangüíneos.

Fica evidente o grau de amadurecimento do tecido da superfície interna medular para o interior, sendo que na superfície interna o osso é alamelar, constituído por fibras colágenas, menos amadurecidas que o osso lamelar da porção óssea mais interna.

Figura 9A (HE) e figura 9B (TM) 


\section{Controle - 120 dias}

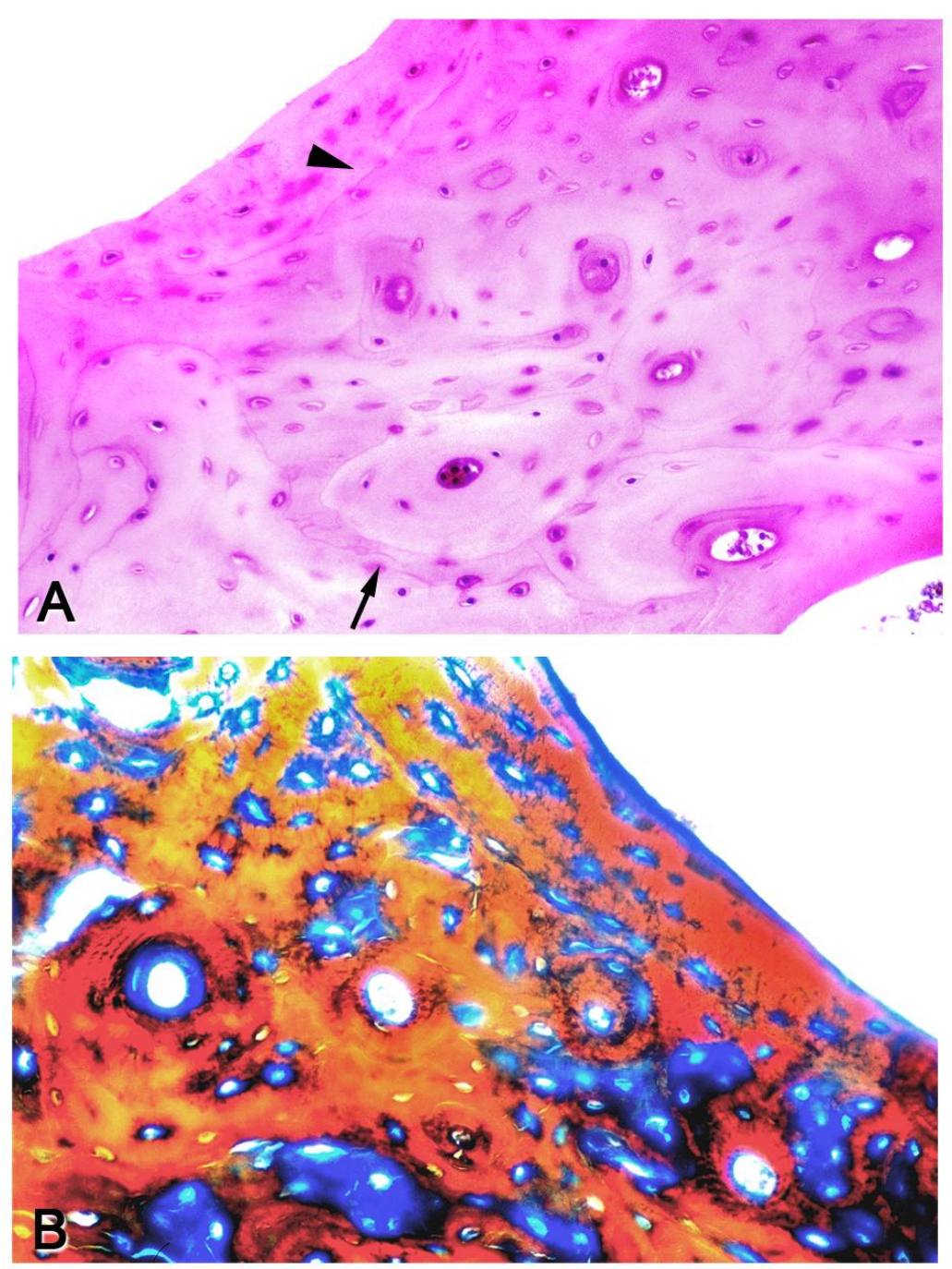

Figura 09: A- Presença de osso lamelar e osso alamelar - HE 857X; B- Diferentes graus de amadurecimento das fibras colágenas - TM 857X. 


\section{Grupo Controle - Período de 150 dias}

A análise pela Hematoxilina e Eosina mostra a presença do osso lamelar, desde a porção interna junto ao canal medular até o corpo da tíbia. As lamelas são concêntricas aos canais de Havers, com diâmetros homogêneos preenchidos por vasos sangüíneos.

Os osteocitos são numerosos e ocupam as lacunas de Howship

Figura 10A (HE)

$\mathrm{Na}$ análise pelo Tricomico de Mallory, as fibras colágenas formam lamelas concêntricas aos canais de Havers, que se encontram rodeados por osteócitos, que se apresentam altamente ramificados.

Figura 10B (TM) 


\section{Controle - 150 dias}
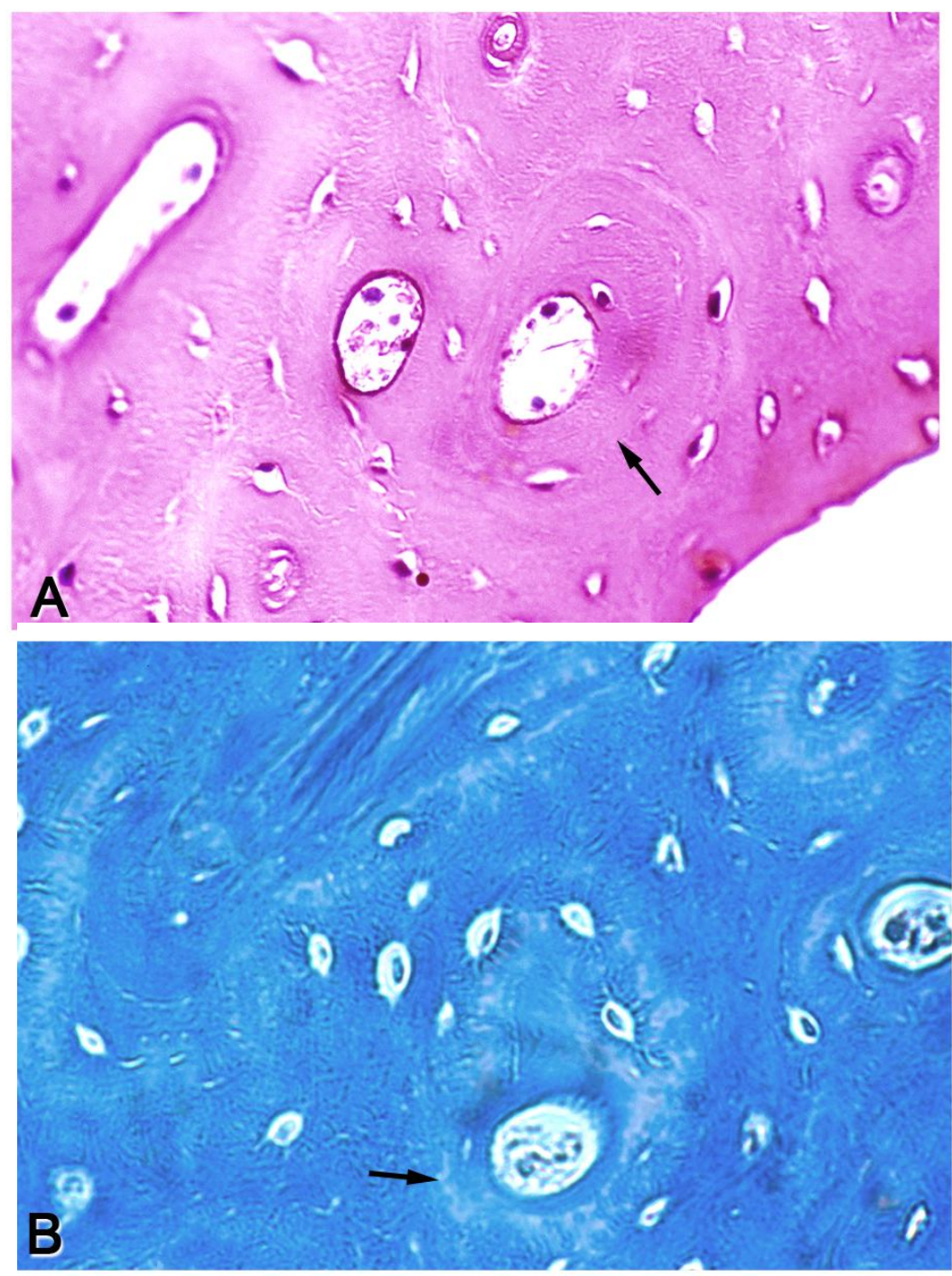

Figura 10: A- Osso maduro lamelar - HE 857X; B- Lamelas com osteócitos ramificados TM 857X. 


\section{ANÁLISE IMUNOISTOQUÍMICA}

\section{Expressão de metaloproteinase da matriz-2 (MMP-2)}

Foi observada marcação positiva para MMP-2 em osteoblastos e osteócitos no período experimental inicial e após 90, 120 e 150 dias após fresagem dos canais medulares, com ou sem inserção do polímero da mamona.

No grupo submetido à fresagem e inserção do polímero, pode ser observado aos 90 dias um aumento na porcentagem de osteócitos positivamente marcados para MMP-2 da ordem de $20 \%$ em comparação ao período inicial previamente à fresagem ( $\mathrm{p}<0,05)$. Esse aumento se manteve até o período de 150 dias após a implantação do polímero (Figura11)

No grupo submetido à fresagem sem implantação do polímero não foi observada modulação da expressão de MMP-2 nos períodos de 90, 120 e 150 dias uma vez que a porcentagem de osteócitos positivos para MMP-2 foi semelhante à observada previamente à implantação ( $p$ > 0,05) (Gráfico 1 e Tabela 2, 3 e 4).

Para controle da técnica e da presença de marcação não-específica, lâminas foram incubadas com Imunoglobulina G, sem o anticorpo primário, e pode-se observar ausência de marcação intra e extra-celular. 


\section{MMP-2}
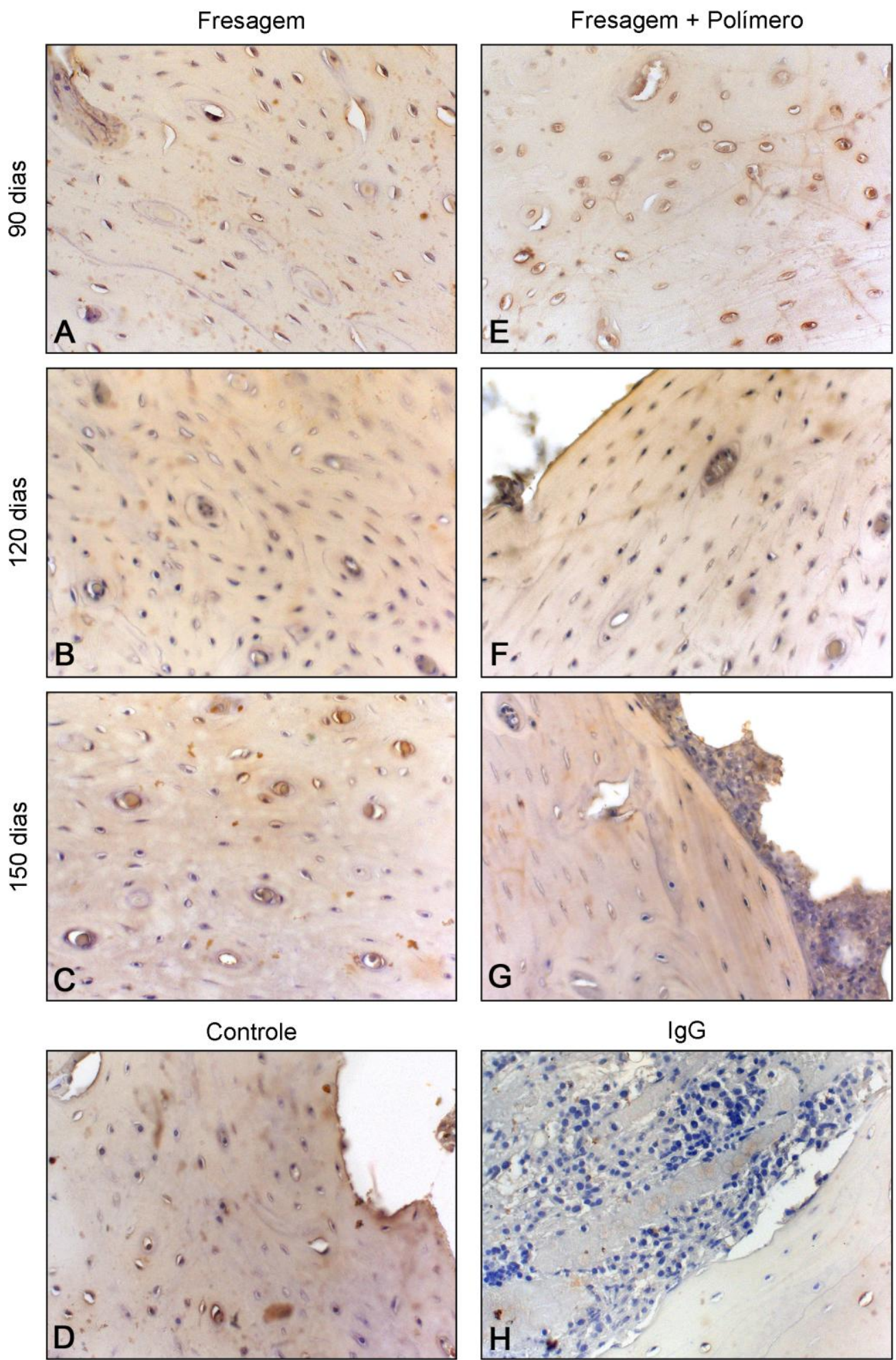

Figura 11. Imagens das lâminas dos espécimes submetidos à eutanásia, 90, 120, 150 dias e controle, após implantação ou não do polímero da mamona. IgG representa lâmina na qual foi omitido o anticorpo primário e as lâminas foram incubadas com imunoglobulina G. Aumentos: A, D, E-20X; B, C, F, G - 40X; H -10X. 
Tabela 2. Porcentagem de células positivas para MMP-2 por campo de visão, previamente e após 90, 120 e 150 dias da fresagem dos canais medulares da tíbia de coelhos, com ou sem implantação do polímero da mamona.

\section{MMP-2}

Fresagem sem polímero

Fresagem com polímero

\begin{tabular}{ccccccccc}
\hline & controle & 90 & 120 & 150 & controle & 90 & 120 & 150 \\
\hline & 40 & 38 & 42 & 45 & 40 & 60 & 65 & 64 \\
& 39 & 42 & 44 & 43 & 39 & 62 & 68 & 65 \\
& 42 & 43 & 44 & 40 & 42 & 63 & 64 & 60 \\
& 40 & 38 & 42 & 45 & 40 & 60 & 65 & 64 \\
& 39 & 42 & 44 & 43 & 39 & 62 & 68 & 65 \\
& 42 & 43 & 44 & 40 & 42 & 63 & 64 & 60 \\
\hline mean & 40,3333 & 41 & 43,3333 & 42,6666 & 40,3333 & 61,6666 & 65,6666 & 63 \\
\hline SD & 1,36626 & 2,36643 & 1,03279 & 2,25092 & 1,36626 & 1,36626 & 1,86189 & 2,36643 \\
\hline
\end{tabular}

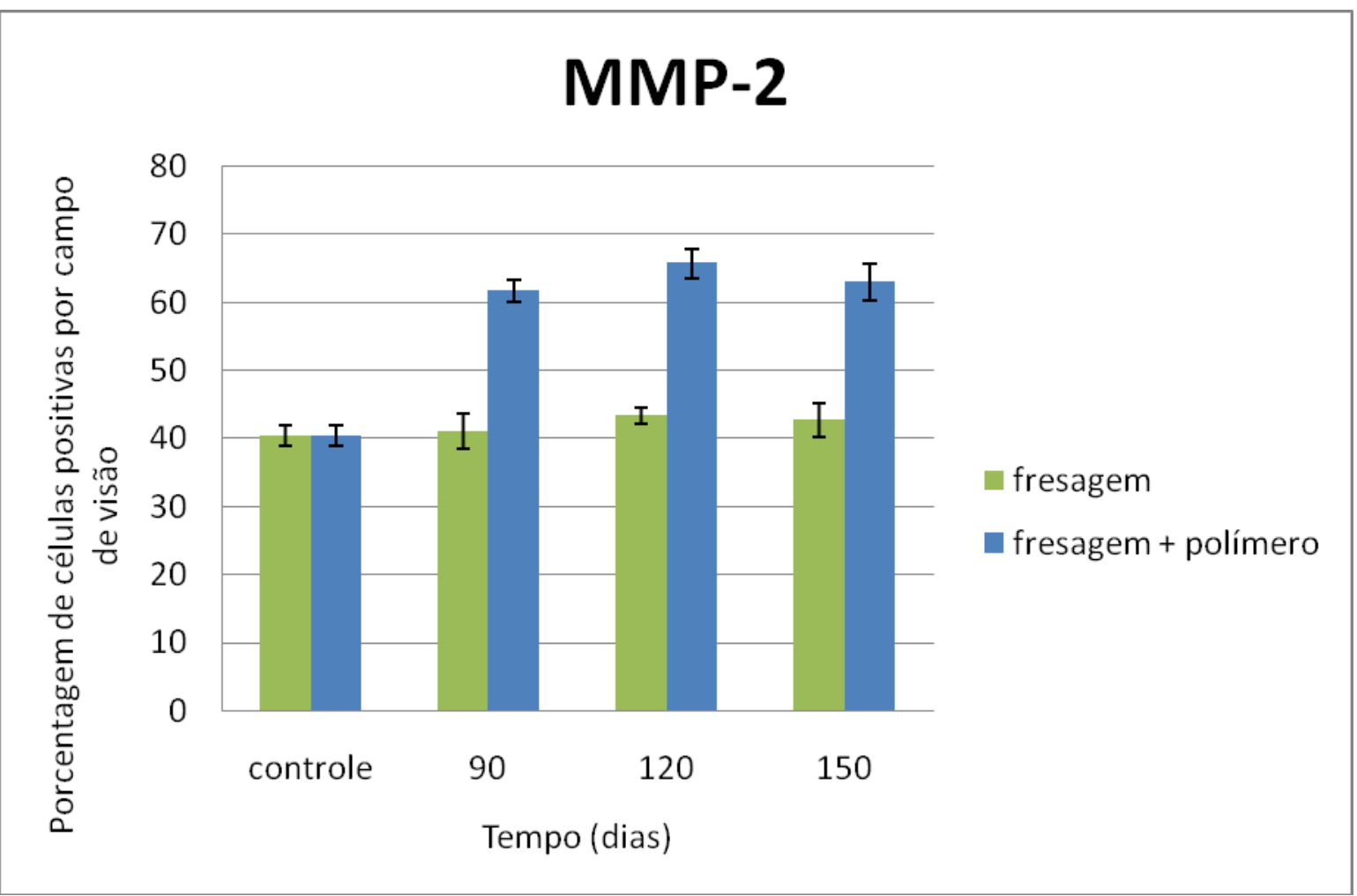

Gráfico 1. Porcentagem de células positivas para MMP-2 por campo de visão, previamente e após 90, 120 e 150 dias da fresagem dos canais medulares da tíbia de coelhos, com ou sem implantação do polímero da mamona. 
MMP-2

Tabela 3. Resultado das comparações entre períodos utilizando o Teste de Tukey

\begin{tabular}{lcc}
\hline & Grupo fresagem & Grupo fresagem + polímero \\
\hline Controle $\times 90$ dias & $p>0,05$ & $p<0,05$ \\
Controle $\times 120$ dias & $p>0,05$ & $p<0,05$ \\
Controle $\times 150$ dias & $p>0,05$ & $p<0,05$ \\
90 dias $\times 120$ dias & $p>0,05$ & $p>0,05$ \\
90 dias $\times 150$ dias & $p>0,05$ & $p>0,05$ \\
120 dias $\times 150$ dias & $p>0,05$ & $p>0,05$ \\
\hline
\end{tabular}

Tabela 4. Resultado das comparações entre grupos utilizando o Teste de Tukey

\begin{tabular}{|c|c|c|c|c|c|}
\hline \multicolumn{2}{|c|}{90 dias } & \multicolumn{2}{|c|}{120 dias } & \multicolumn{2}{|c|}{150 dias } \\
\hline fresagem & $\begin{array}{c}\text { fresagem + } \\
\text { polímero }\end{array}$ & Fresagem & $\begin{array}{l}\text { fresagem }+ \\
\text { polímero }\end{array}$ & fresagem & $\begin{array}{c}\text { fresagem + } \\
\text { polímero }\end{array}$ \\
\hline \multicolumn{2}{|c|}{$p<0,05$} & \multicolumn{2}{|c|}{$p<0,05$} & \multicolumn{2}{|c|}{$p<0,05$} \\
\hline
\end{tabular}




\section{Expressão de metaloproteinase da matriz-9 (MMP-9)}

Foi observada marcação positiva para MMP-9 em osteoblastos e osteócitos no período experimental inicial e após 90, 120 e 150 dias após fresagem dos canais medulares, com ou sem inserção do polímero da mamona (Figura12).

No grupo submetido à fresagem e inserção do polímero pode ser observado aos 90 dias uma porcentagem de osteócitos positivamente marcados para MMP-9 semelhante àquela observada no período inicial, previamente à fresagem $(\mathrm{p}>0,05)$. Com o passar do tempo, foi observado pequena porcentagem de células marcadas, tanto no período de 120 como 150 dias após a implantação do polímero, sem diferença estatisticamente significante entre os períodos $(\mathrm{p}>0,05)$.

No grupo submetido à fresagem sem implantação do polímero não foi observada modulação da expressão de MMP-9 nos períodos de 90, 120 e 150 dias uma vez que a porcentagem de osteócitos positivos para MMP-9 foi semelhante à observada previamente à implantação (p > 0,05) (Gráfico 2; Tabela 5, 6 e 7).

Para controle da técnica e da presença de marcação não-específica, lâminas foram incubadas com Imunoglobulina G, sem o anticorpo primário, e pode-se observar ausência de marcação intra e extra-celular. 


\section{MMP-9}
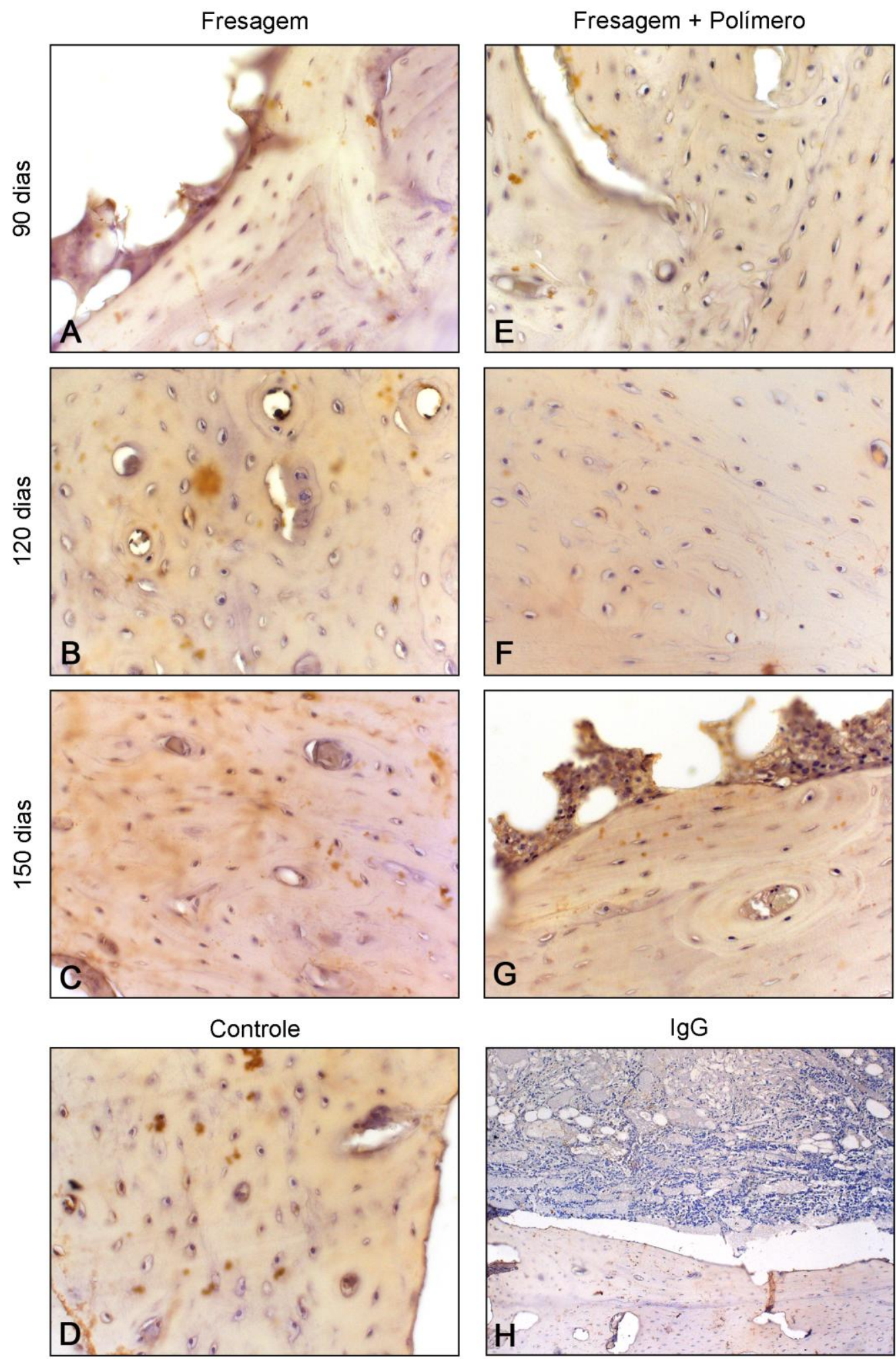

Figura 12. Imagens das lâminas dos espécimes submetidos a eutanásia, 90, 120, 150 dias e controle, após implantação ou não do polímero da mamona. IgG representa lâmina na qual foi omitido o anticorpo primário e as lâminas foram incubadas com imunoglobulina G. Aumentos: A, B, D, F, H - 20X; C, E, G - 40X. 
Tabela 5. Porcentagem de células positivas para MMP-9 por campo de visão, previamente e após 90, 120 e 150 dias da fresagem dos canais medulares da tíbia de coelhos, com ou sem implantação do polímero da mamona.

\section{MMP-9}

Fresagem sem polímero

Fresagem com polímero

\begin{tabular}{ccccccccc}
\hline & controle & 90 & 120 & 150 & controle & 90 & 120 & 150 \\
\hline & 22 & 17 & 19 & 22 & 22 & 21 & 24 & 26 \\
& 20 & 22 & 25 & 25 & 20 & 28 & 28 & 32 \\
& 23 & 23 & 24 & 24 & 23 & 24 & 25 & 30 \\
& 22 & 17 & 19 & 22 & 22 & 21 & 24 & 26 \\
& 20 & 22 & 25 & 25 & 20 & 28 & 28 & 32 \\
& 23 & 23 & 24 & 24 & 23 & 24 & 25 & 30 \\
\hline mean & 21,6666 & 20,66667 & 22,66667 & 23,66667 & 21,66667 & 24,33333 & 25,66667 & 29,33333 \\
\hline
\end{tabular}

MMP-9

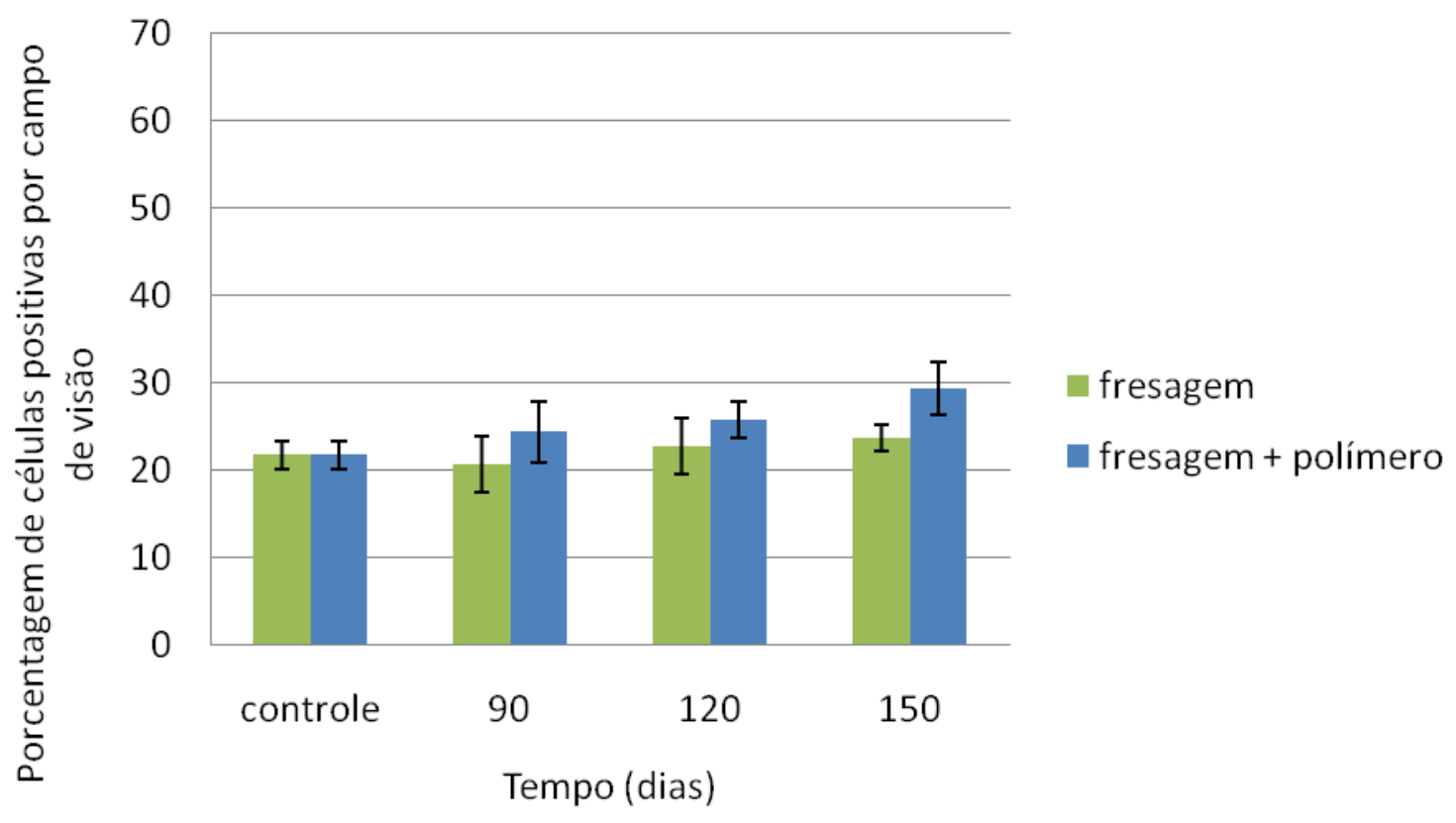

Gráfico 2 . Porcentagem de células positivas para MMP-9 por campo de visão, previamente e após 90, 120 e 150 dias da fresagem dos canais medulares da tíbia de coelhos, com ou sem implantação do polímero da mamona. 


\section{MMP-9}

Tabela 6. Resultado das comparações entre períodos utilizando o Teste de Tukey

\begin{tabular}{lcc}
\hline & Grupo fresagem & Grupo fresagem + polímero \\
\hline Controle $\times 90$ dias & $p>0,05$ & $p>0,05$ \\
Controle $\times 120$ dias & $p>0,05$ & $p>0,05$ \\
Controle $\times 150$ dias & $p>0,05$ & $p>0,05$ \\
90 dias $\times 120$ dias & $p>0,05$ & $p>0,05$ \\
90 dias $\times 150$ dias & $p>0,05$ & $p>0,05$ \\
120 dias $\times 150$ dias & $p>0,05$ & $p>0,05$ \\
\hline
\end{tabular}

Tabela 7. Resultado das comparações entre grupos utilizando o Teste de Tukey

\begin{tabular}{cccccc}
\hline \multicolumn{2}{c}{ 90 dias } & \multicolumn{2}{c}{ 120 dias } & \multicolumn{2}{c}{ 150 dias } \\
\hline \multirow{2}{*}{ fresagem } & $\begin{array}{c}\text { fresagem }+ \\
\text { polímero }\end{array}$ & Fresagem & $\begin{array}{c}\text { fresagem }+ \\
\text { polímero }\end{array}$ & fresagem & $\begin{array}{c}\text { fresagem }+ \\
\text { polímero }\end{array}$ \\
\hline \multicolumn{2}{c}{$p>0,05$} & \multicolumn{2}{c}{$p>0,05$} & $p>0,05$ \\
\hline
\end{tabular}




\section{ANÁLISE TOMOGRÁFICA}

As imagens tomográficas obtidas mostraram o implante de polímero em posição intramedular. O implante foi bem individualizado nas imagens e identificado em cada um dos cortes como pequena estrutura circular homogênea mais densa do que a medula óssea e menos densa do que a cortical óssea. Nos grupos de animais submetidos à eutanásia após 90, 120 e 150 dias da cirurgia de implantação do polímero, as imagens tomográficas não demonstraram alterações significativas na interface implante/medula/óssea. A densidade dos tecidos medida junto a esta interface foi semelhante à densidade das demais porções da medula óssea. Os limites entre o polímero implantado e a cavidade medular são mal definidos nas imagens de tomografia computadorizada, indicando que houve incorporação do material ao tecido neoformado.

$\mathrm{Na}$ interface polímero/canal medular evidenciou-se preenchimento do espaço por tecido ósseo. Não havia sinais de reabsorção óssea ao redor do implante, observados na imagem de tomografia computadorizada, nos grupos de 90, 120 e 150 dias pós-implantação.

\section{Figura 13}

A - Tomografia Computadorizada demonstrando os cortes que foram realizados.

B - Tomografia Computadorizada onde se evidencia o canal medular da tíbia, com sua anatomia preservada e como forma de controle.

C - Tomografia Computadorizada onde se evidencia o canal medular da tíbia, sem implante na diáfise, com fresagem do canal medular.

D - Tomografia Computadorizada onde se evidencia o canal medular da tíbia, com implante na metáfise, sendo que a eutanásia do animal fora realizado no mesmo dia da cirurgia.

\section{Figura 14}

A - Tomografia Computadorizada onde se evidencia o canal medular da tíbia, com implante na diáfise, sendo que a eutanásia do animal fora realizado após 90 dias da cirurgia.

B - Tomografia Computadorizada onde se evidencia o canal medular da tíbia, com implante na diáfise, sendo que a eutanásia do animal fora realizado após 120 dias da cirurgia.

C - Tomografia Computadorizada onde se evidencia o canal medular da tíbia, com implante na metáfise, sendo que o eutanásia do animal fora realizado após 120 dias da cirurgia.

D - Tomografia Computadorizada onde se evidencia o canal medular da tíbia, com implante na diáfise, sendo que a eutanásia do animal fora realizado após 150 dias da cirurgia.

\section{Figura 15}

A - Tomografia Computadorizada onde se evidencia o canal medular da tíbia, com implante na metáfise, sendo que o sacrifício do animal fora realizado após 150 dias da cirurgia.

B - Tomografia Computadorizada comparando-se a eutanásia com implante após a cirurgia e depois de 150 dias. 

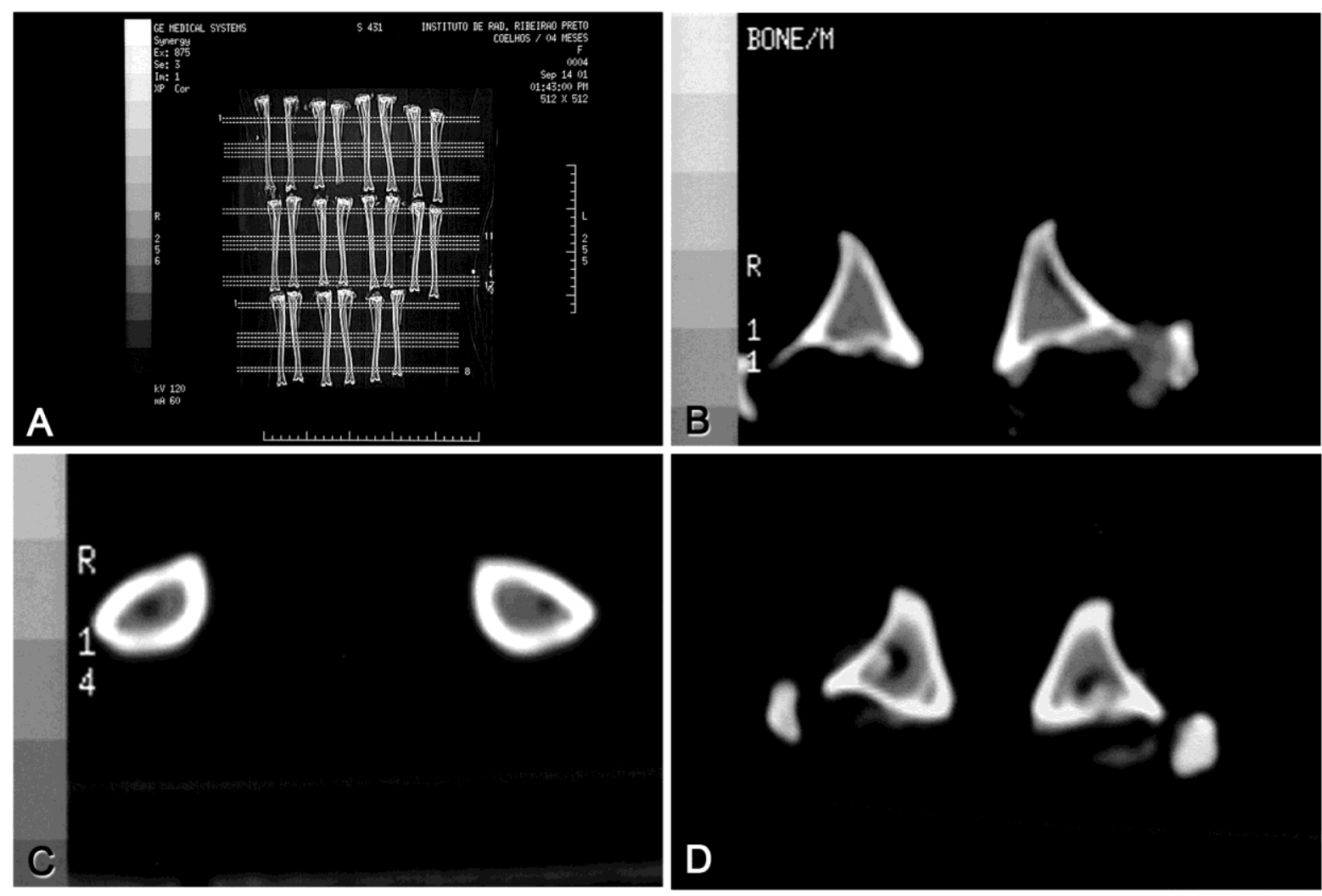

Figura 13: A- Tomografia computadorizada demonstrando os cortes realizados; B- Tomografia computadorizada do canal medular (controle sem fresagem); C- Tomografia computadorizada do canal medular sem implante (controle com fresagem); D- Tomografia computadorizada com implante na metáfise (eutanásia no dia da cirurgia). 
49

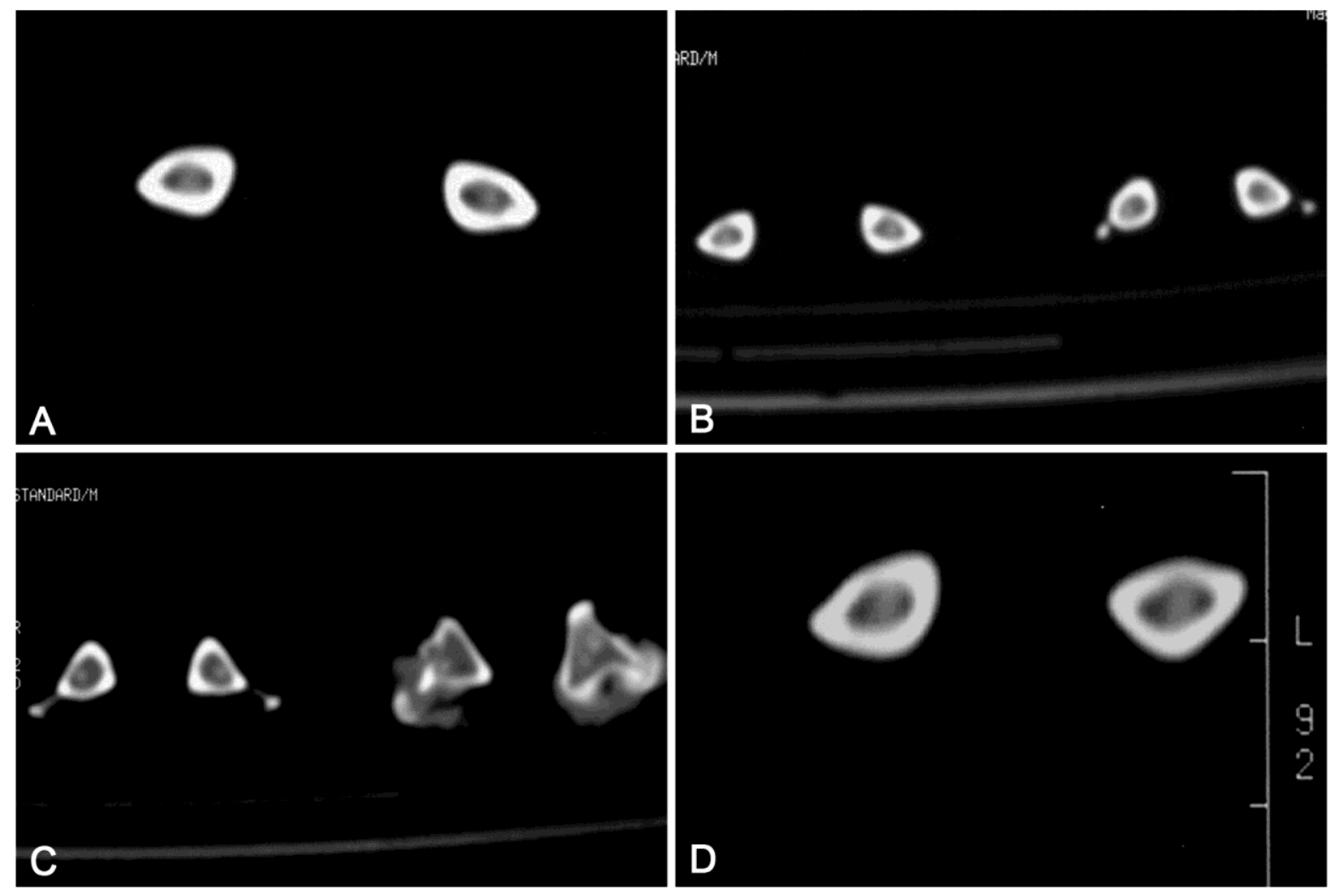

Figura 14: A- Tomografia computadorizada com implante na diáfise (eutanásia 90 dias após a cirurgia); B- Tomografia computadorizada com implante na diáfise (eutanásia 120 dias após a cirurgia); C- Tomografia computadorizada com implante na metáfise (eutanásia 120 dias após a cirurgia); D- Tomografia computadorizada com implante na diáfise (eutanásia 150 dias após a cirurgia). 

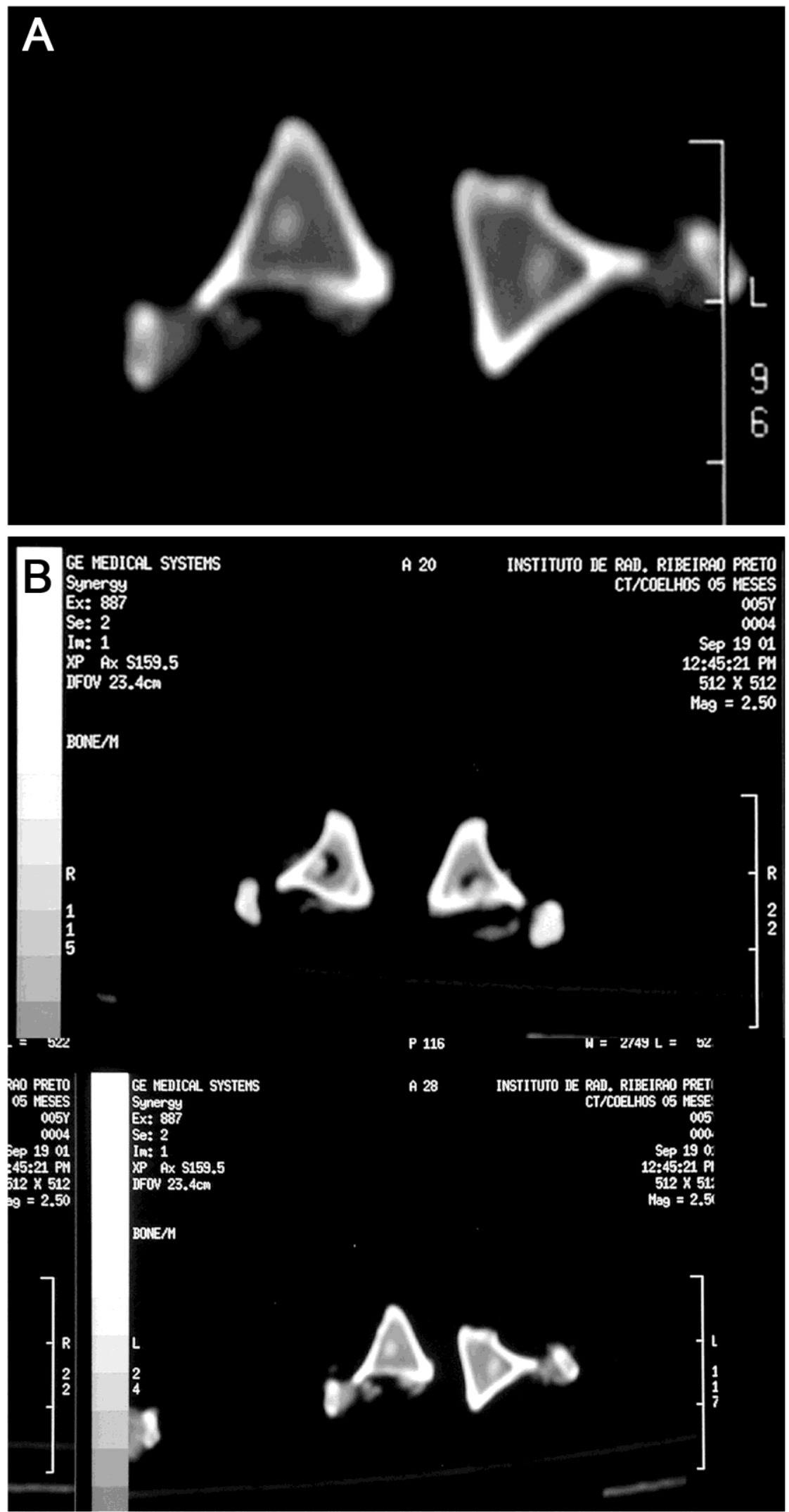

Figura 15: A- Tomografia computadorizada com implante na metáfise ( eutanásia 150 dias após a cirurgia) - ; B- Tomografia computadorizada comparando as metáfises das tíbias com implantes, com eutanásia no mesmo dia da cirurgia e 150 dias após a cirurgia. 


\section{DISCUSSÃO}

A biocompatibilidade do polímero da mamona tem sido evidenciada em inúmeros estudos, quando empregada como material para enxerto/implantes ósseos e em implantes em alvéolos de animais após extração dental (Lamano-Carvalho et al., 1997; König Júnior et al., 1999), fato este também evidenciado por nosso grupo de pesquisa previamente na tíbia de coelhos (Saran, 2006).

Os polímeros emergiram como materiais para implantes biológicos na cirurgia ortopédica, neurocirurgia e otorrinolaringologia em função de suas propriedades biológicas e estabilidade química. Têm sido avaliados, também, na área odontológica, como substituto ósseo e sob a forma de membranas em cirurgias para regeneração óssea (Carvalho et al., 1997).

Com relação à composição, a poliuretana avaliada neste estudo foi derivada de um poliéster sintetizado a partir de óleo de mamona e difenilmetanodiisocianato, composto por: carbonato de cálcio que apresenta a finalidade de aumentar o volume da mistura e permite a formação de poros; pré-polímero rico em NCO livre, derivado do difenilmetanodiisocianato e poliol poliéster; e poliol derivado do polímero poliuretano do óleo da mamona (Chierice, 1994).

A adição do carbonato de cálcio confere melhor padrão de resistência e elasticidade, em relação ao tecido ósseo (Claro-Neto, 1997). Além disso, a associação com o carbonato de cálcio tem a função de fornecer íons cálcio, facilitando a troca iônica na interface de contato osso / polímero, com depósito desses íons na matriz colágena (Ignácio et al., 1997; Kharmandayan, 1997).

Neste estudo, optou-se pela utilização de hastes de poliuretana contendo carbonato de cálcio, em função da facilidade de inserção no canal medular da tíbia de coelhos. Além disso, de acordo com Chierice (1994), este polímero tem uma reação exotérmica de $42^{\circ}$ a $45^{\circ} \mathrm{C}$. Embora tal reação não ocasione lesão celular térmica, neste estudo foi utilizado o material polimerizado, a fim de evitar qualquer geração de calor.

Os resultados obtidos nos grupos experimentais (G2a, G2b e G2c), onde se empregou o polímero da mamona nos períodos de 90, 120 e 150 dias, evidenciaram um processo evolutivo de reparação tecidual, entre a haste derivada do polímero da mamona e o canal medular. No período de 90 dias, observou-se camada espessa de tecido ósseo rico em osteócitos, tecido em processo de maturação e fibras colágenas em organização, com linha reversa nítida delimitando o osso neoformado. No período de 120 dias observou-se franco 
processo de maturação e organização das fibras colágenas, com reparação completa aos 150 dias, não sendo observada reação do tipo corpo estranho com presença de células gigantes como descrito previamente (Lamano-Carvalho et al., 1997; Saran, 2006). A proliferação fibroblástica foi substituída por lamelas ósseas, envolvendo a haste de polímero sendo evidenciada a presença de osso neoformado na interface polímero/canal medular. No período final desse estudo (150 dias), observou-se que o polímero sofreu osteointegração funcional e estrutural com o tecido ósseo organizado (Lamano-Carvalho et al., 1997).

Este tipo de osseointegração direta, ou seja, pelo contato direto do material com o tecido ósseo, é a ideal tendo em vista que uma integração indireta ou fibro-óssea (LeGeros, 1993) é aceitável apenas nos estágios de implantação, por ser desfavorável à estabilidade do implante ou do material de fixação, a longo prazo (Frascino, 1998).

A expressão de metaloproteinase da matriz-2 crescente ao longo do tempo pósimplantação indica que o processo de remodelação óssea está em franco desenvolvimento (Bonfil et al., 2004; Nyman et al., 2011), com maior intensidade nos animais submetidos à fresagem e implantação do polímero se comparado aos animais submetidos à fresagem sem implantação do material. Esta expressão se manteve elevada até o período de 150 dias pósimplantação. A MMP-2 é uma endopeptidase expressa em condições fisiológicas e é importante para a remoção do conteúdo ósseo orgânico durante o processo de maturação óssea.

Por outro lado, a expressão de metaloproteinase da matriz-9 foi menor no tecido ósseo medular se comparado à expressão de MMP-2. O procedimento de fresagem, seguido da implantação do polímero ou sem a implantação do polímero, não levou ao aumento da expressão de MMP-9, em conformidade com os resultados obtidos na análise histológica, tendo em vista que a MMP-9 é expressa principalmente por osteoclastos durante o processo de reaborção óssea ativa (Pasternak e Aspenberg, 2009; Galliera et al., 2010).

Estes resultados indicam que a modulação de metaloproteinase da matriz-2 é importante para o processo de maturação óssea, observado após implantação do polímero da mamona, tendo em vista que nos espécimes nos quais foi realizada a fresagem do canal medular sem implantação do polímero não houve modulação da expressão desta enzima e o processo de neoformação óssea iniciou-se mais tardiamente, com presença de tecido ósseo do tipo alamelar. 


\section{CONCLUSÃO}

A implantação do polímero da mamona após fresagem do canal medular permitiu a neoformação óssea em contato com o material, avaliado por meio de tomografia computadorizada, microscopia óptica convencional e imunoistoquímica.

Aos 90 dias pós-implantação foi evidenciada a deposição de tecido ósseo imaturo, que com o passar do tempo, aos 120 e 150 pós-implantação apresentou uma crescente maturação, adquirindo um aspecto lamelar.

O processo de remodelação óssea observado histologicamente foi acompanhado pela modulação positiva de metaloproteinase da matriz-2 durante todo o período de avaliação, com baixa expressão de metaloproteinase da matriz-9.

O polímero vegetal propiciou a formação de tecido ósseo demonstrado histologicamente pela interação osso neoformado com haste de poliuretana.

Houve indução do processo de formação de tecido ósseo maduro dentro do canal medular ao redor da haste.

O material demonstrou ser biocompatível, não apresentando reação de corpo estranho, pois não foram constatadas células gigantes nas lâminas analisadas.

A imunoistoquímica demonstrou uma franca neoformação óssea, com osso maduro e sem reação inflamatória.

As análises tomográficas mostraram interação polímero/osso.

Os princípios de osteoindução e osteocondução foram demonstrados em todos períodos analisados.

Estudos histológicos não evidenciaram nenhum sinal de infecção nas peças analisadas.

O metabolismo do polímero com substituição por tecido ósseo, evidenciado pelos estudos tomográficos e histológicos e de imunoistoquímica não apresentaram reações adversas de produtos de degradação. 


\section{REFERÊNCIAS}

1. Ara CA. Fijación cervical con polímero vegetal. Neurocir 1999;2(3):103-7.

2. Baadsgaard K. Defect pseudarthroses: an experimental study on rabbits. Acta Orthop. Scand 1970;40(6):689-95.

3. Birkedal-Hansen $\mathrm{H}$. Role of matrix metalloproteinases in human periodontal diseases. $\mathbf{J}$ Periodontal 1993; 64:474-84.

4. Boer HH. The history of bone grafts. Clin Orthop 1988;226:292-8.

5. Bonfil RD, Osenkowski P, Fridman R, Cher ML. Matrix metalloproteinaes and bone metastasis. Cancer Treat Res 2004;118:173-95.

6. Bonini S, Mazzer N, Barbieri $\mathrm{CH}$, Campaneli AP. Resposta inflamatória à poliuretana derivada do óleo de mamona: avaliação da citotoxicidade e ativação de macrófagos em cultura. Rev Odonto Ciênc 2002;17(37):307-17.

7. Bonini S, Mazzer N, Barbieri CH, Lara VS. Resposta inflamatória à poliuretana derivada do óleo de mamona: Estudo da migração e diferenciação de células no sítio inflamatório. Rev Odonto Ciênc 2002;17(35):27-37.

8. Bonini S. Avaliação da resposta inflamatória à poliuretana derivada do óleo de mamona: estudo experimental em camundongos [dissertação]. Ribeirão Preto: Faculdade de Odontologia de Ribeirão Preto - Universidade de São Paulo; 1999.

9. Carvalho TLL, Teófilo JM, Araújo CA, Brentegani LG. Chronology of alveolar healing following immediate implantation of Ricinus Communis polyurethane resin: histometric analysis in rats. J Biomed Mater Res 1997;37(4):449-52.

10. Cavalieri I, Sá-Lima JR, Gomes MF. Estudo do processo de reparação óssea entre os implantes de polímero de mamona, resina acrílica termicamente ativada e cimento ósseo em tíbias de coelhos. BCI 2001;8(29):64-70.

11. Chierice GO. Pesquisa e desenvolvimento de biomateriais, baseados em poliuretanas derivadas de óleo de mamona. SNM - PADCT II; 1994.

12. Claro-Neto S. Caracterizações físico-químicas de um poliuretano derivado de óleo de mamona para implantes ósseos [tese]. São Carlos: Instituto de Física e Química de São Carlos - Universidade de São Paulo; 1997.

13. Del-Carlo RJ, Kawata D, Viloria MIV, Oliveira DR, Silva AS, Marchesi DR, et al. Polímero derivado de mamona acrescido de cálcio, associado ou não à medula óssea autógena na reparação de falhas ósseas. Ciênc Rural 2003;33(6):1081-8.

14. Frascino LF. Implante de resina poliuretana vegetal em cranioplastia: estudo experimental em coelhos [dissertação]. São José do Rio Preto: UNESP; 1998. 
15. Galliera E, Banfi G, Corsi MM. Human bone disorders: pathological role and diagnostic potential of matrix metalloproteinases. Int J Biochem Cell Biol 2010;42(10):1590-3.

16. Garcia-Júnior IR. Utilização dos implantes de polietileno-mrfpor, poliuretana de mamoma e matriz óssea bovina em defeitos ósseos maxilares: análise histológica e histométrica em macacos [tese]. Araçatuba: Universidade Estadual Paulista; 2000.

17. Hannas AR, Pereira JC, Granjeiro JM, Tjäderhane L. The role of matrix metalloproteinases in the oral environment. Acta Odontologica Scandinavica 2007; 65:1-13.

18. Hayakawa T. Matrix metalloproteinases (MMPs) and tissue inhibitors of metalloproteinases (TIMPs) in development and disease of oral tissues. Dent Japan 1998;34:167-77.

19. Ignácio H, Mazzer N, Barbieri CH, Chierice GO. Utilização da poliuretana da mamona nas formas compacta e porosa no preenchimento de falha óssea: estudo experimental em cães. Rev Bras Ortop 2002;37(5):187-94.

20. Ignácio H, Mazzer N, Barbieri CH, Chierici G. Uso da poliuretana derivada do óleo de mamona para preencher defeitos ósseos diafisários segmentares do rádio. Estudo experimental em coelhos. Rev Bras Ortop 1997;32:815-21.

21. JARCHO, M. Calcium phosphate ceramics as hard tissue prosthetics. Clin. Orthop., v. 157, p. 259-278, 1981.

22. Junqueira LC, Carneiro J. Biologia celular e molecular. Rio de Janeiro: Guanabara Koogan; 2005.

23. KONIG JÚNIOR, B.; Beck, T. J.; Kappert, H .F.; kappert, C. C.; MASUKO, T> S>, A study of different calcification areas in newly formed bone 8 weeks after insertion of dental implants in rabbit tibias. Ann Anat, v.180, p. 471-75, 1998.

24. Korlof B, Nylen B, Rietz K. Bone grafting of skull defects. Plastic Reconstr Surg 1973;52:378.

25. Kumar V, Abbas AK, Fausto N. Robbins and Cotran pathologic basis of disease. Philadelphia: Elsevier Saunders; 2005.

26. LAMANO-CARVALHO, T. L.; BRENTEGANI, L.G.; BOMBONATO, K. F., Histrometric analysis of alveolar wound healing. BRAZ DEN J., v.8, n.1, p. 9-12, 1997.

27. LEGEROS, R2. Strategies to affect boné remodeling: osteointegration. J. Bone Mineral Res. 1993; 8:583-96.

28. Leonel ECF, Porciúncula HF, Andrade-Sobrinho J, Oliveira LT, Mangilli PD. A presença do calo ósseo na neoformação óssea promovida pelo polímero de mamona. 


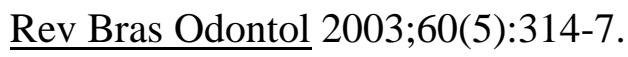

29. Leonel ECF, Porciúncula HF, Andrade-Sobrinho J, Ramalho LTO, Castro MS, Mangilli PD. Avaliação da reação óssea após a colocação de membrana e pino derivados do óleo de mamona na mandíbula de ratos. Rev Paul Odontol 2003;25(5):12-5.

30. Miller TA, Ishida KB, Kobayashi M, Wollman JS, Turk AE, Ralph HE. The induction of bone by an osteogenic protein and the conduction of bone by porous hydroxyapatite: a laboratory study in rabbit. Plast Reconst Surg 1991;87(1):87-95.

31. Navarro VP, Nelson-Filho P, Silva LAB, Freitas AC. The participation of matrix metalloproteinases in the physiopathological processes of the oral cavity. Rev Odontol UNESP 2006; 35(4): 233-38.

32. Nyman JS, Lynch CC, Perrien DS, Thiolloy S, O'Quinn EC, Patil CA, et al. Differential effects between the loss of MMP-2 and MMP-9 on structural and tissue-level properties of bone. J Bone Miner Res 2011;26(6):1252-60.

33. Page-McCaw A, Ewald AJ, Werb Z. Matrix metalloproteinases and the regulation of tissue remodelling. Nat Rev Mol Cell Biol 2007;8(3):221-33.

34. Parks WC, Wilson CL, López-Boado YS. Matrix metalloproteinases as modulators of inflammation and innate immunity. Nat Rev Immunol 2004;4:617-29.

35. Pasternak B, Aspenberg P. Metalloproteinases and their inhibitors-diagnostic and therapeutic opportunities in orthopedics. Acta Orthop 2009;80(6):693-703.

36. Popak MP, Padilha-Filho JG, Canola JC, Castro MB. Poliuretana de mamona (Ricinus communis) para desvio da crista tibial no cão. Cienc Rural 2004;34(3):821-7.

37. Puricelli E, Baraldi CE, Ponzoni D, Peschke R. Estudo histológico do polímero poliuretano da mamona implantado no ângulo mandibular de ratos. $\underline{\text { Rev Fac Odontol }}$ Porto Alegre 1999;40(1):37-40.

38. Ribeiro MG. Avaliação clínica e histológica do implante de poliuretana de mamona (Ricinus communis) no espaço alveolar após exodontia do terceiro pré-molar inferior: estudo experimental em eqüinos [tese]. São Paulo: Faculdade de Medicina Veterinária e Zootecnia; 2003.

39. Santoni-Rugiu P. Repair of skull defects by outer table osteoperiostal free grafts. Plastic Reconstr Surg 1969;43:157-161.

40. Saran W.R. Estudo experimental de implantes derivados da resina poliuretana de mamona (Ricinus communis), inseridos no canal medular da tíbia de coelhos: análise da interface osso e implante. Dissertação. Escola de Engenharia de São Carlos; 2006. 100p.

41. Souza AM, Brandt CT, Lima JA. Biopolímero da mamona na reconstrução de falhas 
ósseas após ressecção de tumores no esqueleto apendicular. An Fac Med Univ Fed Pernamb 2002;47(2):116-23.

42. Souza AP, Line SRP. The biology of matrix metalloproteinases. Rev Fac Odontol Bauru. 2002; 10(1):1-6.

43. Teixeira HM, Ramalho LTO. Reação à resina vegetal de mamona durante o processo de reparo em defeitos ósseos induzidos no corpo da mandíbula. Rev Odontol UNESP 1999;28(1):49-61.

44. TESSIER P., Autogenous boné grafts taken from the calvarium for facial and cranial applications. Clin. Plast. Surg. 1982; 9(4):531-8.

45. VAN DE PUTTE KA, VRIST. MR., Osteogenesis in the interior of intramuscular implants of descalcifild bone matrix. Clin. Orthop. Rel. Res. 1965; 43:257-70.

46. YAMADA K. M.; S. J. AKIYAMA LA FRAMME, S. E. Mechanisms of fibronectin and integrim function during cell adhesion and migration. Cold Spring Harb. Symp. Quant. Boil., v.57, p. 203-212,1992. 